\author{
UNIVERSIDADE DE SÃO PAULO \\ FACULDADE DE ODONTOLOGIA DE BAURU
}

LUCI NEIRE APARECIDA ANNIZE

Avaliação da Compreensão Leitora para Adolescentes do Ciclo II do Ensino Fundamental 



\title{
Avaliação da Compreensão Leitora para Adolescentes do Ciclo II do Ensino Fundamental
}

\author{
Dissertação apresentada à Faculdade de \\ Odontologia de Bauru da Universidade de São Paulo \\ para obtenção do título de Mestre em Ciências no \\ Programa de Fonoaudiologia, na área de \\ concentração Processos e Distúrbios da \\ Comunicação. \\ Orientador: Prof $\stackrel{a}{a}$ Dra. Patricia Abreu Pinheiro \\ Crenitte
}

Versão corrigida 


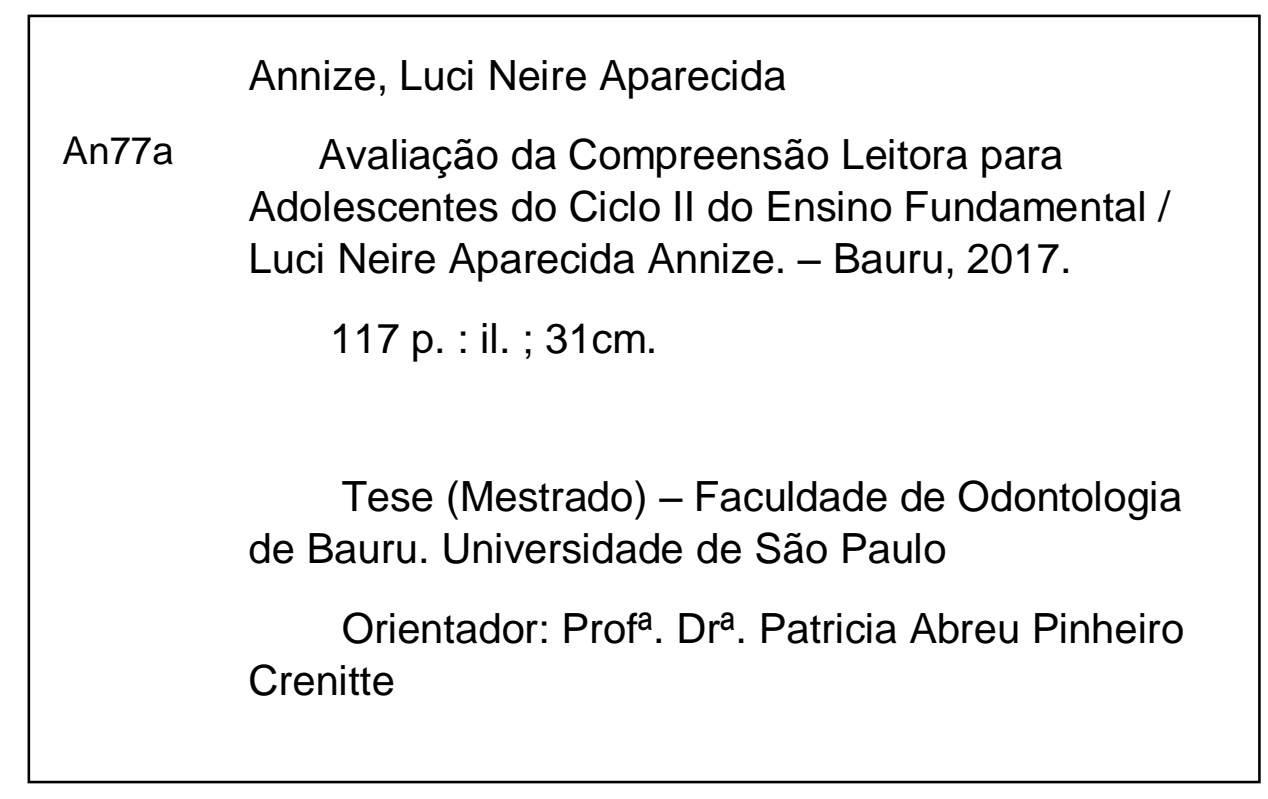

Nota: A versão original desta dissertação/tese encontra-se disponível no Serviço de Biblioteca e Documentação da Faculdade de Odontologia de Bauru - FOB/USP.

Autorizo, exclusivamente para fins acadêmicos e científicos, a reprodução total ou parcial desta dissertação/tese, por processos fotocopiadores e outros meios eletrônicos.

Assinatura:

Data:

Comitê de Ética da FOB-USP

Protocolo no:

Data: 
FOLHA DE APROVAÇÃO 



\section{DEDICATÓRIA}

A Deus, razão de nossa vida cuja presença tem norteado meus dias e guiado meus passos em todos os momentos.

A meus pais, Romildo (in memorian) e Cenira, por todo o incentivo, carinho, exemplo e dedicação ao longo do tempo. A eles, minha eterna gratidão.

A meu irmão Edilson, pelo apoio e estímulo na busca de alcançar os objetivos mesmo diante às dificuldades cotidianas.

A meus filhos, Francesco e Pietro, tesouros inestimáveis, por compreenderem essa etapa em minha vida. 

À minha orientadora, Prof ${ }^{\mathrm{a}}$ Dra Patrícia Abreu Pinheiro Crenitte, por confiar em mim, pela coragem e compreensão na realização desse trabalho, mesmo diante das diversas dificuldades encontradas durante o percurso.

Agradeço-a pela habilidade de partilhar e estimular o conhecimento científico, sabendo me orientar com maestria.

Agradeço-a pelo exemplo e dedicação ao seu trabalho. 



\section{AGRADECIMENTOS}

À Universidade de São Paulo, Faculdade de Odontologia de Bauru, pela oportunidade que tivemos e pelo trabalho desenvolvido com sua equipe;

Aos docentes da Pós Graduação, pela dedicação e partilha de conhecimentos e experiências;

Às professoras e doutoras, Aline Roberta Aceituno da Costa e Dagma Venturini Marques Abramides pela contribuição ao trabalho na banca de qualificação;

À bibliotecária Cybelle Assumpção, que me auxiliou, desde o início do curso e em vários momentos com carinho e compreensão;

À funcionária do Comitê de Ética e Pesquisas em Seres Humanos, Maristela Petenuci, pela presteza e dedicação;

À fonoaudióloga e doutora, Thaís dos Santos Gonçalves, que me orientou com dedicação, dispondo do seu tempo e conhecimento;

Às funcionárias do Departamento de Fonoaudiologia, Claudia, pela solicitude e atenção e Karina, por todo auxílio e empenho;

À minha amiga Claudia Matas, pela força e incentivo em cada etapa do trabalho;

À minha amiga Cris Deziró, pelo estímulo e pelos conselhos;

Aos colegas da Pós Graduação, em especial a Edson Lima, pelo companheirismo de determinados momentos;

À Escola Estadual "Prof. Luiz Castanho de Almeida" com toda a sua equipe que me apoiou no trabalho de pesquisa;

Aos alunos e seus responsáveis, pela colaboração e disposição à pesquisa;

À Ana Lucia, pelo apoio no trabalho de diagramação.

$\mathrm{E}$ a todas as pessoas que não foram citadas mas que colaboraram, indiretamente, para a realização desta Tese de Mestrado. 

"É ao livro, à palavra escrita, que atribuímos a maior responsabilidade na formação de consciência de mundo das crianças e dos jovens"

Nelly Novaes Coelho 



\section{RESUMO}

A presente pesquisa teve por objetivo verificar a compreensão leitora de adolescentes do 9 ำ ano e elaborar programa estruturado para estimulação de leitura. Participaram deste estudo 30 escolares, na faixa de 13 a 17 anos de idade de ambos os gêneros do Ciclo II ( $9^{\circ}$ ano). A coleta de dados foi realizada pela pesquisadora principal, de forma individual com duração de 60 minutos, em até 2 sessões. Foram aplicados os seguintes instrumentos: Avaliação da Compreensão Leitora de textos expositivos, Consciência Fonológica, Acesso ao Léxico Mental e Prova de Memória de Trabalho Fonológica. A partir da análise dos resultados, pôdese observar através do teste de Mann-Whitney que não houve diferença estatisticamente significante quando se comparou o desempenho das habilidades do processamento fonológico entre meninos e meninas. Da mesma forma, quanto às habilidades de compreensão leitora e comparação entre os gêneros observou-se que também não houve diferença estatística, ressaltando que as habilidades que apresentaram maior dificuldade foram as de: relacionar as ideias $(63 \%)$, identificar a organização com perguntas $(87 \%)$ e fazer comentários $(77 \%)$. No que se refere à prova de repetição de dígitos, comprovou-se que os sujeitos recordaram mais dígitos da ordem direta que na ordem inversa e quanto maior o número de sílabas, maior se torna a dificuldade. A consciência fonológica influenciou mais no desempenho da leitura e escrita do que a habilidade silábica, havendo um maior escore de erros no nível fonêmico. $A$ velocidade está diretamente relacionada à fluência de leitura. $O$ estudo sobre a memória do trabalho fonológica evidencia que está associada com habilidades de compreensão da leitura, pois esta requer que partes do texto sejam mantidas por determinado tempo no sistema de memória de trabalho. Essa pesquisa teve sua importância pela observação das dificuldades e avanços de escolares do 9o ano do Ensino Fundamental quanto à compreensão leitora no auxílio aos profissionais.

Palavras chave: leitura, compreensão, escolares. 



\section{ABSTRACT \\ Reading Comprehension Assessment for teenagers Ninth Grade in Elementary School}

This research aimed to verify the reading comprehension of teenagers in 9th grade and elaborate a structured program for stimulating reading. The study included 30 schoolchildren aged 13 to 17 years old of both genders on Elementary School (9th grade). Data collection was performed by the main researcher, individually lasting 60 minutes up to 2 sessions. The following instruments were applied: Reading Comprehension Assessment of expository texts, Phonological Awareness, Access to the Mental Lexicon and Memory Test of Phonological Working. From the analysis of the results, it was observed through the Mann-Whitney test that there was no statistically significant difference when comparing the performance of the phonological processing skills between boys and girls. Likewise, for the reading comprehension skills and comparison between genders, it was observed that there was also no statistical difference, noting that the skills that presented the greatest difficulty were: to relate ideas (63\%), to identify the organization with questions $(87 \%)$ and make comments $(77 \%)$. With regard to proof of digit repetition, it was verified that the individuals reminded more digits of the direct order than in the reverse order and the higher the number of syllables, the greater becomes the difficulty. Phonological awareness has influenced more in the performance of reading and writing ability than syllabic, with a higher error score in the phonemic level. The speed is directly related to reading fluency. The study about the phonological working memory evidences that it is associated with reading comprehension skills, as this requires that parts of the text are maintained for a time in working memory system. This research had its importance due to the observation of the difficulties and advances of schoolchildren from the 9th year of elementary school, as well as the reading comprehension in the help of professionals.

Key words: reading, comprehension, schoolchildren. 



\section{LISTA DE TABELAS}

Tabela 1 - Caracterização da amostra quanto à média de idade ...................... 60

Tabela 2 - Caracterização da amostra quanto à distribuição da idade.............. 60

Tabela 3 - Caracterização da amostra quanto ao gêneros............................ 60

Tabela 4 - Desempenho obtido nas habilidades do processamento fonológico e comparação entre os gêneros.......................................... 67

Tabela 5 - Habilidades de compreensão leitora (após a leitura) e comparação entre os gêneros

Tabela 6 - Correlação das habilidades de compreensão leitora com a consciência fonológica (CF)

Tabela 7 - Correlação das habilidades da velocidade de leitura com a consciência fonológica.

Tabela 8 - Correlação das habilidades de compreensão leitora com a memória de trabalho fonológica.

Tabela 9 - Correlação das habilidades da velocidade de leitura com a memória de trabalho fonológica 

LISTA DE ABREVIATURA E SIGLAS

CF

Consciência Fonológica 
SUMÁRIO

1 INTRODUÇÃO 23

2 REVISÃO DE LITERATURA 27

2.1 A COMPREENSÃO LEITORA 29

2.2 PRÉ-REQUISITO PARA COMPREENSÃO DE LEITURA 34

2.2.1 Consciência fonológica 34

2.2.2 Acesso ao Léxico 39

2.2.3 Memória de trabalho fonológica 40

2.2.4 Programa de estimulação de compreensão leitora 43

3 OBJETIVOS 53

3.1 OBJETIVOS ESPECÍFICOS 55

$4 \quad$ MATERIAL E MÉTODO 57

4.1 ASPECTOS ÉTICOS 59

4.2 PARTICIPANTES 59

4.2.1 Caracterização da Amostra 60

$\begin{array}{lll}4.3 & \text { INSTRUMENTOS } & 61\end{array}$

4.3.1 Avaliação da Compreensão Leitora de Textos Expositivos 61

4.3.2 Prova de Consciência Fonológica - Perfil das Habilidades

Fonológicas - PHF

4.3.3 Teste de Nomeação Automática Rápida - RAN 62

4.3.4 Prova de Memória de Trabalho Fonológica 62

$4.4 \quad$ PROCEDIMENTO 62

5 RESULTADOS 65

5.1 ANÁLISE DOS RESULTADOS 75

6 DISCUSSÃO

7 CONCLUSÕES $\quad 89$

8 REFERÊNCIAS 93

9 ANEXOS 111 

1 Introdução 




\section{1- INTRODUÇÃO}

A leitura é a ação de ler algo e adquirir o hábito de se ler. A palavra deriva do latim "lectura", originalmente com o significado de "eleição, escolha, leitura" (MICHAELLIS, 2009). Para se ler algo se faz necessário a compreensão do significado. Ler é uma arte, uma atividade que denota várias ações conjuntas: a imaginação, a criatividade, o resgate das experiências e as peculiaridades do caráter de cada indivíduo. Assim, tanto ações introspectivas quanto externas influenciam nessa ação (NASCIMENTO, AMORIM, 2016).

Muitas vezes, no contexto escolar, observam-se adolescentes que apresentam certa fluência ao ler, mas não sabem compreender a análise de questões referentes a um texto proposto, por exemplo. O hábito da leitura é de extrema importância ao indivíduo, pois ativa o raciocínio e o senso crítico, desenvolve a imaginação, propicia o acesso a novos conhecimentos e culturas e aumenta o vocabulário. Deve ser despertado na infância a fim de que se aprimore ao longo dos anos.

As políticas de avaliação nacionais têm mostrado o baixo nível de adequação à aprendizagem dos alunos em compreensão leitora da escola básica no Brasil. Conforme os resultados da avaliação do Saeb (BRASIL, 2012), muitos alunos do ensino fundamental, $45,95 \%$ do $5^{\circ}$ ano e $73,04 \%$ do $9^{\circ}$, encontram-se abaixo do nível considerado ideal, causando dificuldades de aprendizagem que são ampliadas de uma série para a outra. Se os problemas de compreensão leitora apresentados pelos alunos do $5^{\circ}$ ano não forem resolvidos durante sua caminhada, por exemplo, as problemáticas refletirão nos anos escolares posteriores.

Os desafios do professor, na escola, são diversos em relação à dificuldade na leitura de seus alunos, especialmente das séries finais do ensino fundamental. Em meio aos benefícios da tecnologia, escolares não se concentram em textos como deveriam e não focam em elementos essenciais para a compreensão leitora, ou seja, crianças e adolescentes precisam se apropriar do conhecimento e não o fazem. Mediante a isso, o papel do educador é detectar, estimular, buscar estratégias, aprimorar conhecimentos e facilitar o caminho de seus alunos para a leitura.

No Brasil, ainda são escassas as pesquisas voltadas para o âmbito da compreensão leitora, principalmente com estudantes na faixa etária de 13 
a 15 anos, o que requer cuidado especial por estarem em constante formação. Estudos têm identificado os componentes da leitura competente, entre eles, reconhecimento de palavras, compreensão e fluência, aspectos que devem ser considerados na avaliação da leitura. Capovilla et al (2016) realizou uma revisão da literatura no recorte 2009 a 2013 com o objetivo de levantar instrumentos de avaliação da leitura nas produções nacionais. Utilizaram-se as bases BVS, PSI, PEPSIC e SCIELO. Aplicados os critérios de elegibilidade, foram selecionados 86 artigos, concentrados em periódicos de psicólogos pedagogia/educação, fonoaudiologia e psicologia. A maioria das investigações utilizou amostras de desenvolvimento típico, com predomínio de estudos com crianças. Foram identificados 52 instrumentos de avaliação, dos quais somente 12 encontram-se publicados. Houve predomínio de testes que mensuram reconhecimento de palavras e apropriados para avaliação infantil. Algumas lacunas identificadas referem -se à avaliação de adolescentes e adultos, bem como de outros componentes da leitura competente.

Linhas de estudo têm intensificado as pesquisas como, por exemplo, o GREPEL (Grupo de Estudo e Pesquisa em Escrita e Leitura) da USP,sobre o referido assunto e reconhecido a necessidade de avaliar 0 desempenho da leitura com estudantes mediante formas e estratégias que busquem sanar dificuldades e estabelecer objetivos norteadores nas práticas pedagógicas, beneficiando profissionais e escolares envolvidos no processo educativo.

O conhecimento de novas maneiras de ver e interpretar os problemas que enfrenta como um ato reflexivo torna-se indispensável ao adolescente de acordo com os documentos dos Parâmetros Curriculares Nacionais. Que este estudo possa contribuir com a identificação das dificuldades na compreensão leitora pelo professor para posterior elaboração de estratégias pedagógicas que visem auxiliá-lo em sua prática diária a fim de que o aluno desenvolva habilidades eficazes no processo da leitura.

Em acréscimo a isso, este trabalho apresenta as características de compreensão leitora de adolescentes e dos aspectos subjacentes à leitura (processamento fonológico), visando o melhor entendimento dos professores que trabalham com a habilidade leitora desta população. 
2 Revisão de Literatura 



\section{REVISÃO DE LITERATURA}

\subsection{A COMPREENSÃO LEITORA}

$\mathrm{Na}$ era digital, há um número significativo de crianças, adolescentes, jovens e até de adultos com diversas dificuldades no âmbito da leitura. Nota-se o período de uma geração que se encontra conectada nas redes sociais e nos aplicativos eletrônicos, no entanto, apresenta dificuldades na compreensão e análise de textos.

A palavra compreender se origina do latim "cum" (preposição com, em companhia de, junto a) e "prehendere" (verbo agarrar, apreender). Quem compreende algo, apanha, apreende para si um sentido ou significado. A compreensão não acontece de forma isolada ou por acaso, ela precisa de uma referência, seja pela leitura de um livro, uma fala, um relato pessoal, a imagem de um quadro, o cartaz de um filme. Compreender é uma ação que é feita na companhia de algo. De acordo com Leffa (2012), leitor e texto só existem no momento da leitura, não podem ficar isolados. Assim, existem contextos ao redor do texto e do leitor que permitem significados para uma melhor compreensão. O sentido ainda não está pronto nem dentro do texto nem dentro do leitor, mas surge durante a transação. (ROSENBLATT, 2004, p. 1369 apud LEFFA, 2012, p. 255).

O domínio da leitura é fundamental para a construção de novos saberes. Não se trata apenas de saber decodificar as palavras e seus significados, mas entender a intenção com que estas são empregadas em determinado contexto. Quando a capacidade produtiva da criança não se desenvolve de forma adequada surgem as limitações, que geram baixa autoestima e pouca aceitação por parte dos colegas (FERREIRA, CONTE \& MARTURANO, 2011). A baixa qualificação aumenta o sentimento de incapacidade e contribui para a manutenção do fraco desempenho (FERREIRA, CONTE \& MARTURANO, 2011; CIA \& BARHMAN, 2008). Os problemas de compreensão da leitura constituem um obstáculo à aprendizagem, pois todas as tarefas escolares (seja de Português, Geografia, História e também de Matemática) requerem que os escolares leiam e extraiam as informações importantes de que precisam para seu aprendizado escolar. Os escolares com problemas de compreensão não conseguem realizar essas tarefas e ficam atrasados em relação aos seus colegas de classe (STOTHARD, 2004; CUNHA, CAPELLINI, 2014). 
A leitura e a escrita envolvem inúmeros processos mentais e funções neuropsicológicas, sendo consideradas, duas atividades altamente complexas. A aprendizagem da leitura é um processo não linear e que sofre muitas interferências de variáveis, devido a essa complexidade. Pela importância da leitura como meio de acesso a novos conhecimentos e da escrita como forma de expressão e uso da linguagem, as dificuldades de leitura e escrita são tema de interesse multidisciplinar, como por psicólogos, pedagogos, neurologistas, fonoaudiólogos, entre outros (SALLES, PARENTE, 2007; FERNANDES, CRENITTE, 2008; SYVERSON, 2008; ZWIERS, 2010; PONTES, DINIS, MARTINS-REIS, 2013). Ler é compreender e compreender é, sobretudo, um processo de construção de significados sobre o texto, é um processo que envolve ativamente o leitor (SOLÉ, 1998; BARBOSA, RODRIGUES, OLIVEIRA, 2011; PONTES, DINIZ, MARTINS-REIS, 2013). No ambiente escolar, o aluno pode obter a oportunidade de conhecer, oferecer e desenvolver suas habilidades cognitivo-linguísticas na interação com atividades a serem propostas pelo professor.

As dificuldades com a leitura geram problemas de compreensão e ocorrem nas mais diversas áreas de estudo. Por isso, algumas pesquisas são feitas no sentido de verificar as causas dessa defasagem linguística e utilizar meios pedagógicos que venham amenizar e esclarecer tais dificuldades partindo do ambiente escolar. Assim sendo, o professor atual, busca parcerias com profissionais de áreas interdisciplinares como o pedagogo, o fonoaudiólogo, o psicólogo, o psiquiatra, o assistente social entre outros a fim de beneficiarem o processo de desenvolvimento da linguagem dos escolares. Entre as competências do profissional especialista em Fonoaudiologia Educacional está a atuação em parceria com os educadores visando contribuir para a promoção do desenvolvimento e da aprendizagem do escolar. Desta forma, a parceria entre professores e fonoaudiólogos, por exemplo, busca a integração de conhecimentos e experiências no ambiente escolar (CRENITTE; GONÇALVES, 2014).

A função de compreender um texto e seus pormenores, o uso de palavras e expressões em seu contexto requer a habilidade de leitura e escrita. Para tal finalidade, os profissionais da educação e comunicação procuram desenvolver atividades ou estratégias de leitura para auxiliar a compreensão leitora entre crianças e adolescentes. Estratégias de leitura são técnicas ou métodos que os leitores usam para adquirir a informação, ou ainda procedimentos ou atividades 
escolhidas para facilitar o processo de compreensão em leitura. São planos flexíveis adaptados às diferentes situações que variam de acordo com o texto a ser lido e a abordagem elaborada previamente pelo leitor para facilitar a sua compreensão (DUFFY\& cols., 1987; BROWN, 1994; PELLEGRINI, 1996; KOPKE, 2001).

Além disso, a utilização de estratégias de leitura compreende três momentos: o antes, o durante e o após a leitura. Na pré-leitura, é feita uma análise global do texto (do título, dos tópicos e das figuras/gráficos), predições e também o uso do conhecimento prévio. Durante a leitura é feita uma compreensão da mensagem passada pelo texto, uma seleção das informações relevantes, uma relação entre as informações apresentadas no texto e uma análise das predições feitas antes da leitura, para confirmá-las ou refutá-las. Depois da leitura é feita uma análise com o objetivo de rever e refletir sobre o conteúdo lido, ou seja, a importância da leitura, o significado da mensagem, a aplicação para solucionar problemas e a verificação de diferentes perspectivas apresentadas para o tema. Também é realizada uma discussão da leitura, com expressão e comunicação do conteúdo lido após análise e reflexão, seguida de um resumo e de uma releitura do texto (KOPKE, 1997; DUKE \& PEARSON, 2002).

A leitura deve e precisa ser monitorada ao aluno pelo professor. Os três momentos esclarecidos acima, quando são elaborados com o devido cuidado de se respeitar a ordem de cada um, tendem a beneficiar o aluno ao notar informações sequenciadas em um texto. Ele pode, inicialmente, organizar o pensamento na ordem cronológica dos acontecimentos de uma estória, por exemplo. E assim, paulatinamente, vai conhecendo e desenvolvendo as habilidades e competências do ato de ler. $\mathrm{O}$ aluno deve ter a oportunidade de enfrentar os desafios da linguagem, como por exemplo, ao conhecer o significado de palavras novas (vocabulário), memorizá-las pela audição do som que as letras e sílabas produzem na formação das palavras, compará-las gradualmente umas às outras e saber o momento de utilizá-las.

No Ensino Fundamental, os alunos do 9ํao já aprenderam algumas habilidades específicas da leitura e desenvolvem outras para assimilar e verificar seu aprendizado. Conforme o Inep (2011), as habilidades do Ensino Médio são acrescentadas com as adquiridas no Ensino Fundamental. A diferença maior entre um nível de escolaridade e o outro é o nível de complexidade dos textos. Dessa 
forma, competências em leitura não adquiridas ao longo do Ensino Fundamental poderá representar um grande problema no decorrer do Ensino Médio. Isso se deve ao fato de os alunos do 9a ano encontrarem-se próximos do início do Ensino Médio, e, ainda, faltarem, a muitos deles, desenvolver competências em leitura importantes para prosseguir na aprendizagem, a saber: estabelecer relação causa/consequência entre partes e elementos do texto; inferir informações; distinguir fato de opinião; diferenciar partes principais de secundárias; localizar a informação principal do texto; identificar efeito de sentido; identificar tese e argumentos presentes em um texto; reconhecer posições distintas em relação a um tema; comparar textos que tratem do mesmo tema.

Pode-se inferir, aqui, que a qualidade da educação básica depende da escola possibilitar aos alunos uma estratégia em lidar com textos que os levem a desenvolver essas competências, ampliando, assim, seus modos de ler. Torna-se necessário o incentivo e acompanhamento do professor em verificar as habilidades e dificuldades de cada aluno. Dessa forma, para que eles desenvolvam essas competências e possam lidar com esses tipos de textos, os discentes necessitam não apenas ter contato com eles de maneira informal, mas de forma sistematizada, para que eles possam "[...] estabelecer vínculos cada vez mais estreitos entre o texto e outros textos, construindo referências sobre o funcionamento da literatura e entre esta e o conjunto cultural [...]" (BRASIL, 1998, p. 71).

As políticas de avaliação nacionais têm mostrado o baixo nível de adequação à aprendizagem dos alunos em compreensão leitora da escola básica no Brasil. Conforme os resultados da avaliação do Saeb (BRASIL, 2012), muitos alunos do ensino fundamental, $45,95 \%$ do $5^{\circ}$ ano e $73,04 \%$ do $9^{\circ}$, encontram-se abaixo do nível considerado ideal, acarretando dificuldades de aprendizagem que são ampliadas de uma série para a outra. Se os problemas de compreensão leitora apresentados pelos alunos do $5^{\circ}$ ano não forem resolvidos durante sua caminhada, por exemplo, e novas competências não forem adquiridas, as problemáticas refletirão nos anos escolares posteriores. Os resultados destas avaliações mostram que a maioria dos alunos brasileiros avaliados é capaz de lidar com informações explícitas ou, ainda, implícitas em um texto; podem fazer conexões nos limites do texto ou com seu conhecimento de mundo; têm a competência de reconhecer a finalidade de um texto e seu tema; podem estabelecer relações entre os elementos 
do texto. Entretanto, muitos desses jovens são capazes de usar tais competências apenas em textos simples.

Em contrapartida, a meta do Índice de Desenvolvimento da Educação Básica (IDEB) dos anos iniciais do Ensino Fundamental ( $1^{\circ}$ ao $5^{\circ}$ ) para 2015 foi alcançada por $74,7 \%$ das redes municipais. O resultado demonstra o esforço dos municípios, que respondem por $82,5 \%$ das matrículas nesse nível de ensino na rede pública. As metas não foram cumpridas nos anos finais do Ensino Fundamental (6ํㅜ ao 9º), apesar do índice ter evoluído. O indicador relaciona o desempenho dos estudantes em avaliações de larga escala, obtidas pela Prova Brasil/Saeb, com dados do fluxo escolar, via Censo Escolar do Ensino Básico. Especificamente na adolescência, na passagem do $9^{\circ}$ ano do ensino fundamental para $01^{\circ}$ ano do ensino médio, há um aumento do nível de complexidade nos textos escritos, o qual nem sempre é acompanhado do necessário desenvolvimento das habilidades de leitura dos jovens (Instituto Nacional de Estudos e Pesquisas Educacionais Anísio Teixeira [INEP], \& Ministério da Educação [MEC], 2001). Segundo Oliveira (2009), o que compromete o país são os milhões de brasileiros matriculados no ensino fundamental, especialmente nas séries iniciais, que são incapazes de escrever uma frase ditada por professores ou de ler um texto e explicar sobre o seu conteúdo. Na avaliação do PISA, a leitura é considerada a principal habilidade avaliada, pois influencia o desempenho dos escolares nas demais habilidades também avaliadas, como matemática e ciências (SILVA E MOURA, 2014, www.inep.gov.br).

Para GERMANO E CAPELLINI (2017), a compreensão da leitura realizada de modo competente torna-se, portanto, o objetivo final da aprendizagem da leitura. Entretanto, diversos fatores concorrem para que a compreensão de textos se realize, porém são insuficientes para, de forma isolada, determiná-la. Têm especial atenção os fatores linguísticos, tais como o processamento fonológico que ancora a capacidade de decodificar, o vocabulário e o conhecimento sintático indispensáveis na compreensão; os fatores cognitivos memória de trabalho, monitoramento e a capacidade de estabelecer inferências, bem como os fatores sociais, que envolvem as circunstâncias em que a leitura ocorre (contexto social, objetivos, motivações e expectativas do leitor), e os conhecimentos prévios do leitor, adquiridos através de sua vivência sociocultural. Dentre essas, as habilidades metalinguísticas de consciência fonológica mostram-se preditoras do 
desenvolvimento da leitura, pois, ao início da alfabetização, o escolar precisa desenvolver sensibilidade à estrutura interna das palavras, ou seja, deve ser capaz de identificar e manipular fonemas e sílabas, para assim posteriormente decodificálas.

Acredita-se que exista uma relação entre essas habilidades com decodificação, a fluência e a compreensão de leitura. Ainda para Uvo, Germano e Capellini, (2017) há relação direta entre a decodificação e a compreensão; de acordo com os autores, dificuldades encontradas na decodificação resultariam, como consequência, dificuldades de compreensão leitora. Sendo assim, após adquirir as habilidades metalinguísticas, o escolar será capaz de realizar a conversão de símbolos gráficos em som, decodificando-os e realizando o reconhecimento das palavras. A compreensão baseia-se no conhecimento dessas habilidades, mas também no conhecimento do vocabulário, processo de reconhecimento sintático, fluência de leitura e na capacidade de fazer inferências, além de atenção, memória, compreensão da linguagem falada e as funções executivas (planejamento, organização, controle de informação).

Ainda neste contexto NICOLIELO-CARRILHO e HAGE (2017) relataram que em seu estudo, as crianças com Distúrbio de Aprendizagem evidenciaram déficits na utilização de estratégias metacognitivas de leitura quando comparadas às crianças sem dificuldade de aprendizagem. Quanto melhor o desempenho na escala de estratégias de leitura, melhor foi o desempenho na compreensão dos textos e vice-versa, sugerindo que habilidades metacognitivas para leitura contribuem para a compreensão leitora.

Complementando as autoras acima, PESTUN (2005), ROSAL et al. (2016), pesquisas têm demonstrado que o domínio fonológico exerce grande influência no processo de aprendizagem da leitura e da escrita, uma vez que este possibilita a generalização dos sistemas. Habilidades do Processamento Fonológico (PF), consciência fonológica, acesso ao léxico e memória de trabalho são fundamentais para a aquisição e o desenvolvimento da leitura e da escrita, e estas habilidades precursoras da leitura serão tratadas logo a seguir.

\subsection{PRÉ-REQUISITO PARA COMPREENSÃO DE LEITURA}

\subsubsection{Consciência fonológica}


A Consciência Fonológica (CF) é a habilidade metalinguística de reconhecimento das características formais fonológicas ou da estrutura sonora da linguagem. Refere-se ao conhecimento de manipular intencionalmente a estrutura sonora das palavras desde a substituição de um determinado som até a sua segmentação em unidades menores (CUNHA, CAPELLINI, 2011; KAMINSKI, MOURA, CIELO, 2011; ROSAL, CORDEIRO, QUEIROGA, 2013; SILVA, MOURA, WOOD, HAASE, 2015), ou seja, acesso consciente ao nível fonológico da fala e a manipulação cognitiva das representações a este nível (PESTUN, 2005). A CF constitui um fator importante no desenvolvimento da leitura e escrita (GUIMARÃES, 2005), ela é uma precursora para a leitura formal (WALCOTT; SCHEEMAKER; BIELSKI, 2010).

Há na literatura várias pesquisas envolvendo a variável gênero, relacionada às diferenças anatômicas e funcionais do cérebro; desvios fonológicos, desenvolvimento da linguagem aprendizagem e dificuldades de aprendizagem, evidenciando diferenças importantes. Porém, são escassas as pesquisas que consideram a variável gênero e a CF como foco principal da investigação.

Em estudos (MOURA, 2008, CIELO et. al, 2010) foi verificado que meninas possuem maior habilidade para analisar pequenos segmentos, já os meninos desempenharam melhor as tarefas de análise com palavras.

Pesquisar como o desenvolvimento das habilidades em CF acontece em cada gênero possibilitaria maior compreensão sobre o processo e uma abordagem com orientações específicas a cada caso (CIELO et. al 2010).

A consciência fonológica, ou seja, a identificação, a segmentação e manipulação intencional de unidades sonoras da fala, são imprescindíveis para o desenvolvimento da habilidade de leitura, uma vez que a recodificação fonológica torna possível a conversão das letras em seus sons correspondentes (SARAIVA, MOOJEN, MUNARSKI, 2006). Leitores menos habilidosos apresentam um déficit em consciência fonológica quando comparados aos bons leitores (WAGNER\& TORGESEN, 1987). A consciência fonológica consiste na capacidade de refletir conscientemente sobre as unidades sonoras das palavras e de manipulá-las de modo intencional (GOMBERT, 1990; FREITAS, 2004; MORAIS, 2006). Essa capacidade não é constituída por uma única habilidade, que a criança teria ou não, 
mas por um conjunto de habilidades distintas, que se desenvolveriam em momentos diferentes (GOUGH; LARSON; YOPP, 1995). Dentre as diversas capacidades de reflexão fonológica, destacamos, por exemplo, a identificação e a produção de rimas ou de aliterações; a contagem de sílabas orais de palavras; a segmentação de palavras em sílabas; e a comparação de palavras quanto ao número de sílabas.

Tal como observaram Freitas (2004) e Morais (2006), trata-se, portanto, de habilidades distintas (como identificar, produzir, contar, segmentar, adicionar, subtrair), com diferentes níveis de complexidade, e que envolvem, também, distintas unidades linguísticas (como sílabas, fonemas e unidades maiores que um fonema, mas menores que uma sílaba). É preciso esclarecer, portanto, que "consciência fonológica" não é sinônimo de "consciência fonêmica" ou de "método fônico", uma vez que o que consideramos como "consciência fonológica" é mais abrangente que a consciência fonêmica, envolvendo não apenas a capacidade de analisar e manipular fonemas, mas também, e sobretudo, unidades sonoras como sílabas e rimas.

Como as distintas habilidades de reflexão fonológica não se desenvolvem ao mesmo tempo podemos considerar que a consciência fonêmica é mais uma consequência do que um requisito para a apropriação do Sistema de Escrita Alfabético. Por outro lado, a consciência de unidades silábicas ou de rimas envolve habilidades menos complexas que as fonêmicas e, portanto, se desenvolvem mais cedo que essas últimas (FREITAS, 2004; MORAIS, 2006).

A correlação entre a consciência fonológica e o desempenho em atividades de leitura e escrita foi descrita em diversos estudos, sendo motivo de controvérsias. Três diferentes posições são apontadas pelos pesquisadores. Em uma primeira posição, estão aqueles que acreditam que a consciência fonológica (como habilidade para detectar rima e aliteração) é preditiva do progresso na aquisição da leitura e escrita devido ao uso de analogias, habilidade de perceber que duas palavras rimam, que podem tornar a criança sensível às semelhanças ortográficas no final dessas palavras e, assim, possibilitar o estabelecimento de conexões entre padrões ortográficos e sons no final delas. Para esses autores (COSTA, 2002; CIELO, 2002; GRAIG, 2003; ANTHONY; LONIGAN, 2004; CIRINO et al, 2005; LAZZAROTTO; SAVAGE et al, 2005; GRAY, McCUTCHEN, 2006; PUOLAKANAHO, 2007; JONG, 2007; KAMPS et al, 2008), a consciência fonológica é considerada a chave para o desenvolvimento da alfabetização. Este papel central 
da consciência fonológica sobre a aprendizagem da leitura e da escrita é atestado, segundo os autores, por numerosos trabalhos de pesquisa, com seus resultados demonstrando que o desempenho de crianças pré-escolares em determinadas tarefas de consciência fonológica relaciona-se com o sucesso na aquisição da leitura e da escrita.

Muitos autores, como Graig (2003), Cirino et al, (2005), Savage et al (2005), Jong (2007), Puolakanaho (2007), não especificam diferentes níveis de consciência fonológica, valendo-se deste termo de uma forma geral. Ao passo que outros autores, como Paula (2002), Barrera e Maluf (2003), Freitas (2003), Godoy (2003), Moojen et al (2003), Zorzi (2003), Romero (2004), Cárnio e Santos (2005), Paes e Pessoa (2005), consideram que a consciência fonológica desenvolve-se de uma consciência mais rudimentar (rimas, aliteração), para níveis mais complexos, das sílabas até os fonemas; esses autores utilizam o termo consciência fonológica para consciência de rimas, aliteração e sílabas, por exemplo, e a consciência fonêmica para a consciência de fonemas.

Nos últimos vinte anos, estudos têm demonstrado que o escolar com distúrbio de aprendizagem apresenta falha nos processamentos cognitivo, linguístico, auditivo e visual e que, em decorrência dessas falhas, o acionamento de mecanismos cognitivos para analisar, sintetizar, manipular, estocar e evocar informações linguísticas encontra-se alterado, prejudicando, assim, a aprendizagem do princípio alfabético de sistemas de escrita como o português, o inglês, o francês, o espanhol, o italiano, entre outros (SILVA, 2009). Desse modo, na literatura, a intervenção proposta para escolares com distúrbio de aprendizagem tem focado a necessidade do ensino de estratégias metafonológicas visando desenvolver a atenção e percepção ao som da fala em associação ao domínio do mecanismo de conversão grafema-fonema necessário para a aprendizagem da leitura e da escrita em um sistema de escrita alfabético, como o do português brasileiro.

Anthony e Lonigan (2004) acreditaram que as habilidades fonológicas, isto é, a sensibilidade geral das crianças para a estrutura dos sons da linguagem, representa um papel importante para aprender a ler e a soletrar dentro de um sistema alfabético. Os resultados de seu estudo mostraram que a sensibilidade fonológica pode influenciar o início da aquisição de leitura por múltiplos caminhos, inclusive leitura por analogia e leitura por meio de correspondência de letra-som. A 
sensibilidade para rima acrescenta uma vantagem para ler por analogia e a sensibilidade de fonemas soma uma vantagem para ler pela correspondência letrasom. Os autores também reconhecem que a maioria das influências na leitura é compartilhada por essas duas habilidades de sensibilidade fonológica. Além disso, sensibilidade para rima foi um significante preditor de sensibilidade de fonemas.

Para Gindri, Keske-Soares e Mota (2007), o conhecimento alfabético requer uma série de habilidades fonológicas especializadas. Inicialmente, a consciência fonológica permite às crianças representar os segmentos de som na linguagem escrita, no entanto, aprender a ler solicita tipos mais avançados de consciência fonológica. À medida que as crianças tomam consciência de tipos diferentes de unidades fonológicas, como as sílabas, rimas e fonemas, e aprendem a manipulá-las, há concomitante avanço da leitura. Estudos realizados por esses pesquisadores evidenciaram que os estágios iniciais da consciência fonológica colaboram para o desenvolvimento dos estágios iniciais do processo de leitura. Esses, por sua vez, colaboram para o desenvolvimento de habilidades de consciência fonológica mais complexas. Assim, parece que, enquanto a consciência de alguns segmentos sonoros, como a rima, aliteração e sílabas, desenvolvem-se espontaneamente, a consciência fonêmica parece depender de experiências específicas com a linguagem escrita que possibilitem a identificação da correspondência entre os elementos fonêmicos da fala e os elementos grafêmicos da escrita. Dessa forma, algumas habilidades de processamento fonológico seriam pré-requisitos para a aquisição da linguagem escrita e, ao mesmo tempo, a competência em leitura e escrita promoveria o desenvolvimento dos níveis mais refinados de processamento fonológico, estes por sua vez, promovem níveis mais avançados da leitura, gerando uma relação de causalidade recíproca.

Estudos realizados por Hay e colaboradores (2007) indicam que há fortes evidências de que crianças com problemas associados com fonologia, síntese, semântica e sistema linguístico vão apresentar dificuldades para o aprendizado da leitura no início do período escolar. Cirino e colaboradores (2005) também constataram a existência de uma forte relação entre as habilidades de processamento fonológico, mais especificamente a consciência fonológica e a habilidade de leitura de palavras, com os resultados indicando o papel relevante da consciência fonológica no desempenho da leitura, particularmente na decodificação de palavras. 
Godoy (2003), Ryder, Tunmer e Greaney (2008) argumentaram que, dentre as habilidades específicas, a consciência fonológica tem sido apontada como uma competência fundamental para a formação de leitores proficientes no sistema alfabético, sendo que algumas formas de consciência fonológica desenvolvem-se espontaneamente por meio da experiência linguística, enquanto outras, como a consciência fonêmica e a habilidade de manipular fonemas, não dependem da maturidade cognitiva e só podem ser alcançadas por meio de instrução explícita estimulada, por exemplo, pelo ensino do sistema alfabético. Para os autores, há a necessidade de se considerar níveis distintos de habilidades fonológicas.

\subsubsection{Acesso ao Léxico}

Wagner et al. (1997), Brizzolara et al. (2006), Vulkovic, Siegel, 2006 e Miranda-Casas et al., (2010) afirmam que o Acesso ao Léxico possui relação com a leitura, principalmente em habilidades de decodificação, fluência e compreensão.

Um dos principais objetivos do ensino da leitura é garantir o desenvolvimento da leitura fluente (WOLF et al., 2000). Para que esta fluência de leitura seja estabelecida é necessário o desenvolvimento do processamento automático e sem esforço das informações gráficas, os quais liberam os recursos atencionais para as tarefas de ordem superior, como a compreensão de leitura (LOGAN, 1997; WOLF; KATZIR-COHEN, 2001).

A habilidade de nomeação automática rápida é uma aptidão bastante estudada, a qual permeia os processos de leitura (DENCKLA \& RUDELL, 1976). Para se avaliar esta habilidade, geralmente utiliza-se a mensuração da velocidade de nomeação de itens familiares, tais como letras, dígitos, objetos e cores. Os itens devem ser nomeados o mais rápido possível, seguindo a orientação espacial da esquerda para a direita e de cima para baixo, de forma análoga à leitura de textos (JONES et al., 2016).

A Nomeação Automatizada Rápida (RAN - Rapid Automatized Naming; DENCKLA \& RUDELL, 1974) também denominada velocidade de nomeação, recuperação lexical, recodificação fonológica de acesso ao léxico (CAPELLINI, FERREIRA, SALGADO \& CIASCA, 2007) está diretamente relacionada à fluência de leitura (MISRA et al., 2004). Quanto melhor for a habilidade do leitor em reconhecer 
40

palavras escritas de forma ágil e precisa, mais serão os recursos cognitivos disponíveis para a tarefa de compreensão leitora (CARDOSO-MARTINS \& PENNINGTON, 2001).

A leitura envolve certa sobreposição no processamento de vários itens, e verifica-se um processo análogo durante as tarefas de nomeação seriada rápida (JONES et al., 2008). Dessa forma, o reconhecimento visual e o tempo de nomeação de letras individuais são prejudicados na presença de informações semelhantes (letras com propriedades visual-ortográficas ou fonológicas semelhantes), principalmente em leitores disléxicos (JONES et al., 2016).

Portanto, a simples tarefa de nomeação rápida requer a iniciação e condução precisa e rápida das informações lexicais para acessar automaticamente os itens individuais (por exemplo, letras), que então precisam ser rapidamente suprimidas, no intuito de realizar monitoramento e o sequenciamento dos vários itens apresentados.

Para os pesquisadores que consideraram as dificuldades na nomeação rápida como sintomas de alterações no processamento fonológico, a alteração nesta habilidade ocorre particularmente no nível de codificação fonológica (processo de ativação ou acesso direto à informação fonológica durante a produção da palavra falada), e/ou na formação de específicas representações fonológicas (CLARKE et al., 2005; TRUMAN; HENNESSEY, 2006). Este ponto de vista apoia os argumentos de Swan e Goswami (1997a, 1997b), os quais relatam que o desempenho na nomeação por crianças disléxicas é mais sensível a variáveis lexicais que afetam a complexidade da codificação fonológica, como o comprimento da palavra.

O processamento da nomeação seriada rápida tem sido considerada ainda como uma importante ferramenta para discriminar a performance de bons e maus leitores, principalmente à medida que os bons leitores tornam-se mais fluentes (JONES et al., 2009; de JONG, 2011; JONES et al., 2012; GEORGIOU et al., 2013).

\subsubsection{Memória de trabalho fonológica}

Segundo Montgomery (2003), a Memória de Trabalho (MT) é um sistema de processamento e armazenamento de informações em curto prazo que mantém o pensamento, a aprendizagem e a comunicação. A Memória de Trabalho (MT) é também considerada uma habilidade importante para a aquisição e desenvolvimento 
da leitura e da escrita, pois é esta memória a responsável pelo armazenamento temporário da informação para o desempenho de uma série de tarefas cognitivas (BADDELEY, 2003; ZANELLA, VALENTINI, 2016), como aprendizagem, compreensão da linguagem e raciocínio.

A memória é conceituada conforme a sua função, seu tempo de duração e seu conteúdo. Assim, podem ser distinguidos três níveis: memória sensorial, com duração inferior a um segundo; memória de curto prazo, que corresponde a um tempo de alguns segundos a alguns minutos e é sinônimo de memória operacional (capacidade de arquivar temporariamente a informação para o desempenho de diversas habilidades cognitivas); e memória de longo prazo, que cobre um tempo que vai de algumas horas a anos e é dividida em memória implícita e memória explícita. Resumidamente, memória implícita é a memória para habilidades e procedimentos e memória explícita é a memória para fatos e eventos (IZQUIERDO, 2002)

No que tange à linguagem, a memória de trabalho verbal (fonológica) tem um papel fundamental. Estudos encontraram correlações entre as habilidades de memória fonológica e as habilidades de fala e linguagem, afirmando que a memória se expande com a idade, devido ao aumento na velocidade da "rechamada" subvocal, ou seja, o aumento nas habilidades de memória parece estar ligado a um aumento nas habilidades de fala e linguagem (HULME, THOMSON, LAWRENCE, 1984). No entanto, de acordo com Siqueira (2006), a memória, assim como diversas outras habilidades, sofre um declínio diante de alterações biológicas, fisiológicas e psicológicas.

Um estudo que validou teste de memória de trabalho fonológica comprovou a influência da idade, da escolaridade e da extensão das não-palavras no desempenho das crianças, já que as mais velhas e com maior escolaridade apresentaram melhor desempenho. Outro fato observado foi que o desempenho das crianças de todas as faixas etárias diminui conforme o número de sílabas das nãopalavras aumenta. Isso ocorre pelo fato das não-palavras serem retidas por um determinado tempo na memória de trabalho. Assim, quanto maior o número de sílabas das não-palavras, maior a dificuldade do processo subvocal da memória de memória (SANTOS, BUENO,2003). 
No que se refere à prova de repetição de dígitos, comprovou-se que sujeitos recordam mais dígitos na ordem direta do que na ordem inversa. A ordem inversa apresenta maior grau de complexidade, estando assim relacionada com o executivo central, enquanto em ordem direta estaria relacionada com a alça fonológica. Sabe-se ainda que, na ordem direta, crianças foram capazes de memorizar uma média de cinco dígitos e na ordem inversa, três dígitos. Já os adultos foram capazes de memorizar cinco dígitos na ordem direta e quatro dígitos na ordem inversa (FIGUEIREDO, NASCIMENTO, 2007).

Portanto, a memória, assim como outras habilidades cognitivas, evolui com o decorrer dos anos, mas declina na terceira idade e, ainda que quanto maior o número de sílabas, maior a dificuldade em armazenar o material verbal na memória, independentemente da faixa etária (HAGE, GRIVOL, 2009)

De acordo com os estudos realizados por Alloway e colaboradores (2004), a memória de trabalho tem relação direta no desempenho das tarefas de consciência fonológica, sendo a memória de trabalho capaz de reter e manipular temporalmente a informação, enquanto participa de tarefas cognitivas como raciocínio, compreensão e aprendizagem. Acredita-se que quanto maior for essa capacidade de processamento, maiores serão os recursos cognitivos disponíveis para a tarefa de compreensão da leitura, apesar de que a compreensão requer capacidades que vão além do processamento fonológico, tais como: conhecimento prévio; capacidade de realizar inferências; dentre outros (JUSTI, ROAZZI, 2012, NASCIMENTO, AMORIM, 2016).

As informações devem ser mantidas na memória enquanto o leitor segue realizando a leitura do texto. O leitor, por outro lado, não precisa ter a preocupação de manter na memória de trabalho as palavras que leu com precisão, e sim as mensagens principais dos grupos de palavras, armazenando-as sob forma de proposições. As informações que ficarem na memória por um tempo maior serão melhores compreendidas. Contudo, em função dos limites da memória, será preciso que algumas informações sejam excluídas, dando espaço às novas informações (KINTSCH, 1988, 1998). As proposições mais significativas ou temáticas que ajudarão o leitor a compreender melhor o texto ficarão na memória por um tempo maior do que aquelas que não são consideradas relevantes à compreensão do texto. 


\subsubsection{Programa de estimulação de compreensão leitora}

O presente estudo se propõe também elaborar um programa de estimulação para a compreensão de leitura para estudantes do $9^{\circ}$ ano, visto que em nossa realidade educacional, é crescente o número de crianças que apresentam dificuldades no aprendizado da leitura e escrita e que permanecem em sala de aula sem acompanhar as atividades com eficiência. As causas para essas dificuldades são diversas, segundo os professores, e podem ser caracterizadas por déficits visuais e/ou auditivos, dificuldades na fala e na linguagem, fatores emocionais, familiares e sociais, atitudes pouco estimulantes do professor, inadequação de programas escolares entre outros. (MELCHIOR e GABRIEL, 2014). Para Navas; Martin (2010), a compreensão leitora é uma habilidade complexa que envolve diferentes processos desde a decodificação de palavras e memória até 0 conhecimento do mundo. A falta de compreensão leitora gera dificuldades na aprendizagem de vários conteúdos específicos.

Complementando os autores acima, pode-se afirmar que na Prova Brasil, há dez níveis de desempenho em leitura os quais vão de 0-9. As escalas usadas para os alunos do $5^{\circ}$ e do $9^{\circ}$ anos do Ensino Fundamental são as mesmas. Segundo Brasil (2008), os níveis alcançados pelos alunos do $5^{\circ}$ ano deveriam ser mais baixos daqueles atingidos pelos alunos do 9 , visto que, de acordo com o próprio documento, alunos do $5^{\circ}$, normalmente, possuem menos competências leitoras do que os do 9․ O documento alerta, assim, para a necessidade de a escola trabalhar a leitura de forma sistemática, a possibilitar assim que o aluno alcance o final do 9o ano, com a competência não só de localizar informações explícitas nos textos, mas também de identificar as implícitas e as variações da língua portuguesa.

De acordo com dados do PISA (Programa Internacional de Avaliação de Alunos), em 2013, o desempenho de estudantes brasileiros em leitura piorou em relação a 2009 , colocando o país na $55^{\underline{a}}$ posição do ranking de leitura, abaixo de países como Chile, Uruguai, Romênia e Tailândia. O relatório da OCDE afirma que parte desse mau desempenho do país pode ser notado pela expansão de alunos de 15 anos na rede em séries defasadas. Em acréscimo a isso, quase metade $(49,2 \%)$ dos estudantes brasileiros não atinge o nível 2 de desempenho na avaliação que tem o nível 6 como teto, significando que eles não são capazes de deduzir 
informações de um texto, estabelecer relações entre as diferentes partes do texto e não conseguem entender as variações linguísticas.

Além do enfoque nas habilidades acadêmicas, a questão comportamental também tem fundamental importância para que a intervenção gere resultados positivos. Segundo Reschly (2005), uma proporção significativa de crianças com problemas de aprendizagem apresenta problemas concomitantes relacionados à atenção, tempo para resolver tarefas, entre outras dificuldades. As questões comportamentais envolvidas não só no distúrbio de aprendizagem, como em qualquer problema de aprendizagem, devem ser tratadas em conjunto com as deficiências de habilidades acadêmicas, pois sem isso o impacto da intervenção fica diminuído.

Savage e colaboradores (2005) observaram em estudos nos quais foram medidas as habilidades de consciência fonológica, leitura de não-palavras, nomeação automática rápida, memória verbal de curta duração, memória de trabalho e percepção da fala em maus e em bons leitores que os testes de consciência fonológica e a leitura de não-palavras correlacionam-se mais fortemente com as habilidades de leitura, sendo o fator que diferenciou o desempenho dos maus leitores do desempenho dos bons leitores na leitura de palavras, compreensão de leitura e soletração, considerando que a memória de trabalho e o processamento fonológico contribuem para o desenvolvimento inicial da leitura

Bastos (2003) apresenta três características comuns aos alunos com dificuldades de compreensão de leitura, sendo: desconhecimento total ou parcial do significado das palavras, dificuldade em extrair a ideia central dos parágrafos ou textos e não conseguir expressar o que leu com suas palavras.

A relação entre leitura, especialmente a compreensão de leitura textual, e linguagem oral (uma das medidas seria o vocabulário) pode ser justificada pelo fato de que compreender um texto implica combinar conhecimentos sobre linguagem e conhecimentos sobre o mundo (KINTSCH \& VAN DIJK, 1978).

A leitura, para Gagné, Yekovich e Yekovich (1993, p. 135), permite que o mundo passe a fazer parte até da vida de indivíduos que vivem em localidades remotas. Segundo os autores, há quatro níveis de compreensão leitora. Os dois primeiros, chamados de shallow processing, englobam a decodificação e a compreensão literal, níveis em que o leitor é capaz de perceber o texto de uma forma superficial. Já os dois últimos níveis de compreensão leitora: inferência e 
monitoramento, o leitor tem a capacidade de embrenhar-se nos emaranhados do texto, de formar novos conceitos, de posicionar-se perante o texto. Tal nível de processamento é chamado de deep processing - níveis necessários e importantes na formação do leitor, pois é a partir daí que ele lidará com conceitos velhos e novos, fará relações e criará hipóteses. Dessa forma, a leitura é o caminho para a ampliação da percepção do mundo à nossa volta. Quanto mais um indivíduo lê, mais integrado com o meio ele estará. O caminho para chegar a ser um bom leitor consiste em ler muito (KLEIMAN, 2013). E a capacidade para ler e compreender textos é fundamental na nossa vida diária. Quando surge associada ao contexto educativo, reveste-se de uma importância maior porque se trata de um componente indispensável ao desenvolvimento cognitivo do escolar, que compete ao professor atender. (ALVES, 2005).

Compreensão leitora é a faculdade de entender os significados dos textos escritos. É também o processo pelo qual habilidades e estratégias cognitivas são colocadas em funcionamento, permitindo que o leitor construa significados do texto. Fazem parte da compreensão leitora: um texto, um leitor e uma situação comunicativa. $O$ texto é um objeto linguístico e cultural portador de um significado. $O$ leitor constrói significados, saberes, habilidades e capacidades. E a situação comunicativa é a interação entre o leitor e o autor através do texto escrito. É ela que determina, na maioria das vezes, o que e como se compreende os enunciados escritos. Esses três elementos definem o que o leitor lembrará, perceberá ou deixará de perceber a partir do texto, enfim, como ele responderá ao texto escrito e os sentidos que construirá em sua resposta. (KLEIMAN, 2013).

Compreender é, essencialmente, uma atividade de relacionar conhecimentos, experiências e ações num momento interativo e negociado. (MARCUSHI, 2004). Trata-se de um momento único de partilha e interação com a linguagem cujo processo deve ser mediado por profissionais da comunicação. Segundo o autor, os exercícios de compreensão dos livros didáticos costumam falhar em aspectos centrais; os textos não são produtos acabados com todas as informações possíveis e, além disso, ele defende que, na composição dos manuais escolares, a maioria dos exercícios de compreensão leitora é de perguntas e respostas, havendo poucas atividades de reflexão aos escolares, lidando assim com aspectos formais do texto. Se, por um lado, a escola representa um ambiente 
propício de aprendizagem onde a criança inicia seus primeiros passos para o letramento, por outro, a parceria da família é fundamental para o êxito do conhecimento adquirido paulatinamente pelo educando.

A investigação das últimas décadas mostrou-nos que a eficácia da aprendizagem da leitura depende do ensino eficaz da decifração, de ensino explícito de estratégias para a compreensão de textos e do contato frequente com boa literatura.(SIM-SIM, 2007) De acordo com a autora, o ensino da decifração assenta no treino da consciência fonológica e na aprendizagem da correspondência som/grafema; por sua vez, o ensino da compreensão de textos deve buscar a apropriação pelas crianças de estratégias de monitorização da leitura tais como prever, sintetizar, esclarecer e questionar a informação obtida.

Estudos realizados sobre intervenção demonstram que estudantes de risco para dificuldade de leitura, se identificados no início da vida escolar e se for realizada intervenção apropriada, adquirem as habilidades necessárias para obter sucesso em leitura (WANZEK; VAUGHN, 2008; KAMPS, 2008). É uma questão de observação e aplicação em tempo hábil.

Procedimentos que envolvem leitura tem se tornado foco de trabalhos realizados com indivíduos com dificuldades de aprendizagem. Estudos têm indicado a eficácia de programas de remediação associados a estratégias de leitura (KAMPS et al., 2008, WANZEK, VAUGHN, 2008, SILVA, CAPELLINI, 2010, KIM et al., 2010, EHREN, 2012).

Entretanto, apesar da literatura internacional recomendar o uso destes programas de remediação, na literatura nacional, as pesquisas ainda são escassas quando se trata de programa de intervenção.

Estudo (DOCKRELL, MCSHANE, 2000) mostra que os indivíduos com dificuldades de compreensão apresentam menos conhecimento explícito de leitura e estratégias de leitura que os bons leitores. A evidência é bastante consistente de que os indivíduos com dificuldades de compreensão são menos eficazes que o grupo sem dificuldade no uso de estratégias de execução para leitura. O porquê disto ainda permanece indefinido. A compreensão fraca pode ser o resultado de uma dificuldade em dispor de estratégias de execução.

Zwiers (2010) acrescenta que além de ensinar estratégias de compreensão é necessário formar nos alunos o hábito de usá-las para melhor assimilar o que é lido. Entre estes hábitos o autor destaca: analisar a ideia principal 
e resumir o texto; relacionar o lido com o ambiente; fazer inferências e previsões; gerar e fazer questões; compreender e memorizar os significados de palavras; monitorar a própria compreensão (o que implica em auto-avaliação frequente de sua compreensão). Estas aprendizagens devem começar de forma sistemática já na educação infantil e irem evoluindo durante o processo de educação formal. Além disso, cada leitor precisa estar atento ao seu próprio desenvolvimento ao longo de sua vida (SYVERSON, 2008, SILVA, WITTER, 2010, ZWIERS, 2010).

Existem evidências que $O$ uso de estratégias de leitura melhora a compreensão de leitura, principalmente para os escolares que lutam com dificuldades de aprendizagem (EHREN, 2005, GAJRIA et al., 2007). Além disso, Ehren (2005) observa que a compreensão da leitura envolve o uso de uma variedade de estratégias de leitura, em grande parte depende da finalidade de leitura, o tipo de material a ser lido, e os próprios pontos fortes e fracos do leitor.

Profissionais e professores devem estar atentos aos leitores que apresentam dificuldade na compreensão, pois podem desenvolver atividades que permitam a organização das informações apresentadas no texto de forma lógica, construção do significado global do texto e o domínio do seu processo de compreensão, ou seja, oferecer ao leitor estratégias de leitura, a compreensão exigirá o envolvimento do leitor e a utilização de estratégias mentais pode ser estimulada por atividades criadas pelo facilitador.

E neste sentido estudos estão sendo desenvolvidos como o de CORREA e COELHO (2010) que teve como objetivo examinar o progresso da compreensão leitora através do desenvolvimento da habilidade de monitoramento a partir do emprego do paradigma de detecção de erros. Adolescentes distribuídos nos grupos experimentais e controle realizaram as tarefas de monitoramento e leitura (teste de Cloze) como pré-teste e pós-teste, tendo sido controladas: habilidade verbal, atenção e memória de trabalho. Os grupos não diferiram em suas habilidades lingüístico-cognitivas, nem em seu desempenho nas tarefas do pré-teste. Após a intervenção, o grupo experimental foi significativamente melhor do que o grupo controle nas tarefas de leitura e de monitoramento. Tais evidências sugerem que o progresso no desenvolvimento da compreensão de texto está relacionado à eficiência com que os adolescentes monitoram sua leitura. 
MACIEL (2012) realizou um estudo, de natureza quase-experimental, delineou procedimentos para nove sessões de intervenção com o objetivo de avaliar a medida em que uma intervenção com alunos pode neles promover avanços em estratégias de compreensão leitora e motivação. As abordagens teóricas utilizadas nessa investigação foram a Teoria de Expectativa-valor, Teoria do Processamento da Informação, bem como abordagens gerais cognitivistas acerca da compreensão leitora. Participaram do estudo alunos da quinta-série do ensino fundamental de uma escola da rede pública do município de Londrina - PR. As intervenções aconteceram no próprio ambiente escolar. O grupo experimental foi constituído pelos alunos que participavam da sala de apoio e o grupo controle pelos alunos da mesma série escolar que não participavam da sala de apoio. Os alunos foram avaliados em três momentos por meio dos seguintes instrumentos: (a) Escala de Estratégias de Aprendizagem Voltadas para a Leitura; (b) Técnica de Cloze; (c) Avaliação da Autopercepção e Percepção da Tarefa de Adolescentes nos Domínios de Português e de Matemática, e; (d) Problema de Matemática. O Grupo Experimental (GE) participou de nove sessões de intervenção, recebendo apoio motivacional e ensino de estratégias de aprendizagem em situação de leitura. Os resultados mostraram ganhos em compreensão leitora, cuja maioria atingiu um Nível Independente em leitura. Houve melhorias nas estratégias de aprendizagem tanto para o GE quanto para o GC. Os resultados obtidos no presente estudo possam ser úteis a educadores e psicólogos escolares, além de revelarem a importância da formação de docentes capazes de aprender e ensinar de modo estratégico, visando o desenvolvimento da compreensão leitora e da motivação para aprender.

Ainda nesta perspectiva do professor como mediador LEFFA (2013) apresenta um breve estudo sobre a relevância do professor como agente mediador nas aulas de leitura/compreensão textual. Para desenvolver esse trabalho, foram escolhidos alunos do $6^{\circ}$. ano do ensino fundamental II, porque, nessa fase de estudo, os alunos, geralmente, ainda são imaturos no que diz respeito ao processo de leitura e, assim, necessitam mais da intervenção do professor durante a mesma. Esse estudo apresentou, além de conceitos básicos sobre mediação leitora, uma proposta de intervenção com o objetivo de contribuir com uma metodologia de mediação de leitura que possa minimizar eventuais problemas dessa natureza na sala de aula. Para realizar esse estudo, observou-se duas aulas, na $1^{\text {a }}$ série do ensino fundamental II, a fim de verificar as estratégias utilizadas pela docente de 
língua portuguesa e, a partir dessa observação, propor um trabalho com leitura mediada. $\mathrm{O}$ autor defende que práticas de mediação leitora são essenciais para a formação de leitores competentes e que só, por meio de um trabalho sistematizado em torno dessas estratégias, formaremos leitores autônomos.

SALLES (2013) em seu estudo apresentou as contribuições de se promover em sala momentos de leitura e o papel da mediação pedagógica para o desenvolvimento da compreensão leitora durante o período de alfabetização. Nesse sentido, foi utilizado como referencial teórico para se tratar da importância dos gêneros textuais para o ensino da leitura. Tomou-se como referência os descritores de leitura da Provinha Brasil, levando em consideração a relação entre a prática escolar e os descritores desta avaliação. Além disso, busca apresentar conceitos como compreensão e mediação pedagógica para assim subsidiar a reflexão a respeito de estratégias de leitura utilizadas pelo professor durante a mediação da leitura. Diante disso, em vista a alcançar o objetivo proposto, analisar como são desenvolvidas atividades de leitura e qual o papel do professor como mediador da leitura para o desenvolvimento da compreensão leitora, foi realizada uma pesquisa de abordagem qualitativa de cunho etnográfico em uma escola pública do Distrito Federal, nas turmas de $1^{\circ}$ e $2^{\circ}$ anos do Ensino Fundamental. Foram realizadas observações e também foram lecionadas aulas pela pesquisadora. Além disso, também foram utilizados como instrumentos de pesquisa: diário de bordo, questionário e análise documental dos exercícios produzidos pelas crianças. A partir dos resultados obtidos, foi possível concluir que o ensino da leitura e compreensão pautado em gêneros textuais, juntamente com a mediação do professor durante estas práticas viabiliza a alunos em processo de alfabetização ir se constituindo como leitores competentes.

A leitura constitui uma atividade de suma importância na vida de todo ser humano, uma vez que esta prática é condição primordial para o desenvolvimento pleno da pessoa; uma atividade cujo domínio é essencial ao exercício da cidadania, pois é o meio através do qual o estudante tem acesso aos saberes que fazem parte do mundo a sua volta. No entanto, dada a complexidade que envolve o processo de aprendizagem da leitura, ensinar os alunos a ler não constitui tarefa fácil e, muitas vezes, os discentes não adquirem a competência necessária à compreensão dos textos, o que dificulta todo o desenvolvimento destes, haja vista que não há leitura, 
se não houver compreensão. De acordo com essa visão, o estudo de ARAÚJO (2015) teve como foco uma intervenção pedagógica que visa contribuir para o desenvolvimento da competência leitora dos alunos do $6^{\circ}$ ano "U" da Escola Estadual Senador José Bernardo, na cidade de São João do Sabugi - RN. As atividades que constituíram o processo da referida intervenção foram realizadas em sala de aula de Língua Portuguesa e desenvolvidas por meio de sequências didáticas elaboradas a partir de estratégias de leitura, tendo como base os gêneros textuais conto e notícia, uma vez que os alunos, sujeitos desta investigação, apresentavam sérios problemas no tocante à compreensão leitora. Tendo em vista a importância do problema em questão, este trabalho justifica-se pela relevância de atender à dificuldade mencionada, haja vista que o mesmo busca o desempenho em leitura através dos gêneros enquanto práticas sociais de linguagem, por meio de atividades interativas que visam ao ler para compreender, para construir o sentido dos textos e ampliar o interesse pela leitura. Os resultados mostram que os alunos do 6 o ano ampliaram sua capacidade de compreensão dos textos lidos, através da implementação das ações didático-pedagógicas, adquirindo, assim, a competência leitora de que necessitavam para continuar aprendendo.

Para trabalhar a leitura, MACHADO e CAPELLINI (2016) desenvolveu um programa de compreensão leitora por meio da técnica de Cloze. Participaram deste estudo 60 escolares de ambos os gêneros, com idade entre 9 e 11 anos (média = 10,4 anos), do $4^{\circ}$ ano do Ensino Fundamental municipal de uma cidade do interior paulista. Foi desenvolvido um programa de seis treinos com textos selecionados, posteriormente transformados em slides de powerpoint como recurso diferencial para intervenção em compreensão leitora por meio da técnica de Cloze. Os participantes foram divididos em dois grupos, $\mathrm{Gl}$ com 30 escolares que receberam a intervenção e o grupo Gll com 30 escolares que não receberam intervenção de compreensão leitora. Os resultados revelaram diferenças estatisticamente significantes, evidenciando que os escolares apresentaram desempenho obtido superior quando comparado aos escolares que não receberam intervenção do programa de compreensão leitora. A comparação dos resultados do pré e pós-testes apontaram para uma diferença significativa, demonstrando que a técnica de Cloze contribui de maneira salutar para o desenvolvimento da compreensão em leitura.

GONÇALVES-GUEDINI (2017) relata que há evidências que o uso de estratégias de leituramelhora acompreensão, principalmente para os escolaresque 
lutam com dificuldades de aprendizagem. A tradução de instrumentos estrangeiros vem sendo foco de estudos nos últimos anos, devido à escassez de instrumentos. Tal procedimento ameniza a carência e possui grande relevância científica. Tendo em vista a complexidade da aprendizagem e os crescentes problemas educacionais brasileiros, percebe-se a relevância deste estudo, ao buscar a influência da fonoaudiologia na compreensão de leitura em adolescentes com dificuldade de leitura. Para atender tal carência, a autora realizou a tradução e a adaptação do programa Structure Your Reading (SYR) (EHREN, 2008), do Inglês americano para o Português do Brasil. Para verificar a aplicabilidade do instrumento participaram do estudo piloto, 5 escolares, com 14 anos de idade, de ambos os gêneros. Esta etapa revelou a aplicabilidade do instrumento, devido à aceitabilidade e a compreensão dos escolares para tarefas. Sendo assim, concluiu-se que o material ESTRUTURE Sua Leitura, foi traduzido e adaptado de forma satisfatória para língua portuguesa, mostrando-se pertinente para programa de compreensão de leitura, manteve a capacidade de reprodução dos objetivos e competências do mesmo na língua inglesa, também foi possível concluir que os escolares compreenderam as atividades propostas pelo ESL, apresentando bom desempenho no programa. 

3 Objetivos 



\section{OBJETIVO GERAL}

Verificar a compreensão leitora de adolescentes do 9ํano.

\subsection{OBJETIVOS ESPECIFICOS}

$\checkmark$ Comparar o desempenho entre os participantes do gênero masculino e feminino quanto às habilidades do processamento fonológico.

$\checkmark$ Verificar as habilidades de compreensão leitora- após a leitura e comparação entre os gêneros tabela.

$\checkmark$ Verificar a correlação entre as habilidades da Compreensão leitora e CF

$\checkmark$ Verificar a correlação entre a velocidade de leitura e CF

$\checkmark$ Verificar a correlação de compreensão leitora com a memória de trabalho fonológica

$\checkmark$ Verificar a correlação da velocidade de leitura com a memória de trabalho fonológica 

4 Material e Método 



\section{MATERIAL E MÉTODO}

\subsection{ASPECTOS ÉTICOS}

O projeto deste trabalho foi submetido à apreciação pelo Comitê de Ética em Pesquisa com Seres Humanos (CEP) da Faculdade de Odontologia de Bauru da Universidade de São Paulo. O projeto foi aprovado № 1.419.383. Ressalta-se que foram respeitados todos os quesitos que regem a Resolução 196/96, sobre ética em pesquisa com seres humanos do Conselho Nacional de Ética em Pesquisas (CONEP). Os representantes legais tomaram ciência do teor do projeto e assinaram o Termo de Consentimento Livre e Esclarecido (TCLE) anteriormente ao início da coleta e os adolescentes assentiram participar da Pesquisa.

\subsection{PARTICIPANTES}

Participaram deste estudo 30 alunos na faixa etária de 13 a 17 anos, de ambos os gêneros, regularmente matriculados no Ensino Fundamental II de uma escola pública, na cidade de Bauru/SP. Nesta escola havia duas salas do $9^{\circ}$ ano e para a escolha dos participantes foi realizado um sorteio da sala que participaria deste estudo.

Os escolares foram selecionados a partir dos seguintes critérios de inclusão na amostra:

$\checkmark$ Estar matriculado no 9 a ano do Ensino Fundamental;

$\checkmark$ Assinatura do Termo de Consentimento Livre e Esclarecido (TCLE) pelos pais ou responsáveis, bem como assinatura do Termo de Assentimento pelo menor;

$\checkmark$ Ausência de queixas relacionadas ou indicadores de alterações de audição, visão, distúrbios neurológicos, comportamentais ou cognitivos.

Foram adotados os seguintes critérios de exclusão:

$\checkmark$ Pais ou responsáveis que não assinaram o TCLE e participante que não assinou o Termo de Assentimento;

$\checkmark$ Indivíduos que apresentaram diagnósticos de distúrbios de aprendizagem, déficit de atenção e hiperatividade ou outros transtornos neurológicos e psiquiátricos. 
60

\subsubsection{Caracterização da Amostra}

É de relevância a caracterização da amostra, uma vez que auxilia no delineamento e conhecimento dos indivíduos pesquisados. As Tabelas 1 e 2 mostram a caracterização dos adolescentes da amostra, quanto à média e distribuição da idade, respectivamente.

Tabela 1 - Caracterização da amostra quanto à média de idade

\begin{tabular}{|c|c|c|c|c|c|}
\hline & $\mathbf{n}$ & Média & $\begin{array}{l}\text { Desvio } \\
\text { padrão }\end{array}$ & Mínimo & Máximo \\
\hline $\begin{array}{l}\text { Idade } \\
\text { (anos) }\end{array}$ & 30 & 14,17 & 0,79 & 13 & 17 \\
\hline
\end{tabular}

Tabela 2 - Caracterização da amostra quanto à distribuição da idade

\begin{tabular}{ccc}
\hline $\begin{array}{c}\text { Idade } \\
\text { (anos) }\end{array}$ & Frequência & Porcentagem \\
\hline $\mathbf{1 3}$ & 3 & $10 \%$ \\
\hline $\mathbf{1 4}$ & 22 & $73,3 \%$ \\
\hline $\mathbf{1 5}$ & 3 & $10 \%$ \\
\hline $\mathbf{1 6}$ & 1 & $3,3 \%$ \\
\hline $\mathbf{1 7}$ & 1 & $3,3 \%$ \\
\hline Total & 30 & $100 \%$ \\
\hline
\end{tabular}

Observa-se que quanto à idade, a maior porcentagem esteve relacionada na faixa etária dos 14 anos, com 22 alunos (73,3\%); 3 (10\%) com idade de 13 anos; $3(10 \%)$ com 13 anos; $1(3,3 \%)$ com 16 anos e 1(3,3\%) com 17 anos, portanto 0 mais velho do grupo de 30 alunos.

A Tabela 3 mostra a caracterização dos adolescentes quanto ao gênero, sendo constituída por 18 meninas (60\%) e 12 meninos (40\%) num total de 30.

Houve maior número de meninas e variação de idade entre 13 a 17 anos.

Tabela 3 - Caracterização da amostra quanto ao gênero

\begin{tabular}{ccc}
\hline Gênero & Frequência & Porcentagem \\
\hline Feminino & 18 & $60 \%$ \\
\hline Masculino & 12 & $40 \%$ \\
\hline Total & 30 & $100 \%$ \\
\hline
\end{tabular}




\subsection{INSTRUMENTOS}

Os seguintes instrumentos foram utilizados na avaliação do processamento fonológico sob orientação e supervisão de uma fonoaudióloga e pós doutoranda:

\subsubsection{Avaliação da Compreensão Leitora de Textos Expositivos (SARAIVA, MOOJEN, MUNARSKI, 2006)}

Este instrumento foi utilizado para avaliar a compreensão de leitura dos escolares. O objetivo deste material foi avaliar a compreensão leitora de textos expositivos, ou seja, observação e análise de aspectos cognitivos, metacognitivos e motivacionais do leitor. O teste é composto por 18 textos expositivos, no qual são sugeridos para séries específicas, porém não se limita seu uso para alunos de outras séries, dependendo das características do leitor e dos objetivos do examinador. Por esse motivo, ao final de cada texto, há o número de palavras, sem a sugestão da série. Tanto a leitura silenciosa como a oral poderá ter o tempo medido, a fim de verificar a média de palavras lida por minuto. Após a leitura, o examinador solicitou ao escolar que ele relatasse oralmente o que leu e o que aprendeu, sem consultar o texto. Há também um protocolo para avaliação da compreensão leitora e de outros componentes da leitura. Esta ficha está organizada partindo da concepção de que a construção do significado do texto inicia antes da leitura, quando o leitor ativa seus conhecimentos prévios, continua durante a leitura e se completa após, quando ele integra seus conhecimentos com as informações vinculadas pelo texto, respondendo perguntas ou fazendo comentários que vão além das informações nele contidas.

\subsubsection{Prova de Consciência Fonológica - Perfil das Habilidades Fonológicas - PHF (ALVAREZ; CARVALHO; CAETANO, 1998)}

O instrumento teve como objetivo avaliar a consciência fonológica. O PHF avalia a consciência silábica e fonêmica por meio de tarefas de rima sequencial, reversão silábica, adição, subtração e substituição. 
62

4.3.3 Teste de Nomeação Automática Rápida - RAN (FERREIRA, 2004)

O teste mediu a velocidade do sujeito em acessar e recuperar atividades verbais na nomeação de diversos estímulos visuais (nomeação de cores, dígitos, letras e objetos).

\subsection{4 - Prova de Memória de Trabalho Fonológica (HAGE; GRIVOL, 2009)}

O teste permitiu a avaliação da memória fonológica e consiste na repetição de 40 pseudopalavras que variavam conforme o número de sílabas, de duas a cinco sílabas. Ainda, o avaliado terá que repetir dígitos na ordem direta e inversa. Para cada resposta correta na primeira tentativa foram atribuídos dois pontos, já para respostas corretas na segunda tentativa foi atribuído um ponto. 0 teste foi interrompido após dois erros consecutivos.

\subsection{PROCEDIMENTO}

A coleta de dados foi realizada pela pesquisadora, de forma individual com duração de 60 minutos, em até 2 sessões. Todos os procedimentos foram realizados numa sala de uma Escola Estadual de Ensino Fundamental no interior de São Paulo, conforme declaração de anuência da escola. Para avaliar a compreensão de leitura, utilizou- -se o texto preconizado em Avaliação da Compreensão Leitora de Textos Expositivos (SARAIVA, MOOJEN, MUNARSKI, 2006). A avaliação foi realizada de acordo com os critérios do instrumento. Os textos utilizados foram os indicados para escolares da 9a série. Definiu-se com cada participante o objetivo da leitura, contextualizando a situação: ler para mostrar o que aprendeu com o texto. Os escolares escolheram o texto a ser lido, dentre os dois oferecidos, perguntou-se o que sabiam sobre o tema (a partir do título e gravura); Caso o escolar demonstrasse conhecer a maioria das informações, a pesquisadora sugeria a leitura de outro texto. Solicitou-se também que realizasse a leitura silenciosa. Posteriormente solicitou-se uma nova leitura, só que oralmente Os dois tipos de leitura tiveram o tempo medido - palavras lidas por minuto.

Ex: Texto "Os morcegos" № de palavras: 208 
Tempo despendido em segundos: 2 minutos e 36 segundos $=156$ segundos

$X-156$

$X-60^{\prime}$

Após a leitura, solicitou-se que o escolar - sem consultar o texto relatasse oralmente o que leu e aprendeu. Se fosse necessário, a pesquisadora poderia utilizar as perguntas orientadoras anexadas ao texto. As perguntas de inferências foram feitas, para observar se os escolares eram capazes de irem além do texto.

A Consciência Fonológica foi avaliada por meio do Perfil de Habilidades Fonológicas (ALVAREZ; CARVALHO; CAETANO, 2004), que fornece dados sobre a capacidade do indivíduo de processar os aspectos fonológicos da língua. Nesta prova, os escolares foram são submetidos a diversas tarefas, cada uma avaliando uma habilidade de CF (análise inicial, análise final, análise medial, adição, segmentação frasal, segmentação vocabular, subtração, recepção de rimas, rima sequencial, reversão silábica e imagem articulatória). Os dados para comparação com a normalidade são classificados de acordo com a idade cronológica e variam entre 5 e 10 anos de idade.

O acesso ao léxico foi avaliado por meio do Teste de Nomeação Automática Rápida - RAN (Rapid Automatized Naming), desenvolvido por Denckla e Rudel (1976) e padronizado para a população brasileira por Ferreira, Tonelotto, Ciasca e Capellini (2003). Este teste foi utilizado para medir a velocidade de nomeação. $O$ procedimento é composto por quatro sub-testes de nomeação, que inclui a nomeação de: cores, dígitos, letras e objetos. Cada um é composto por cinco estímulos diferentes, que se alternam, formando 10 linhas seqüenciais em um total de 50 estímulos. $O$ de cores é composto pelas cores verde, vermelho, preto, azul e amarelo. O de letras é composto pelas letras "p", "d", "o", "a" e "s". O de dígitos é composto pelos números "6", "2", "4", "9" e "7" e o sub-teste de objetos é composto pelas seguintes figuras: pente, guarda-chuva, chave, relógio e tesoura. $O$ tempo de nomeação em cada prova é cronometrado para posterior análise. Os índices de comparação de normalidade são classificados de acordo com a série escolar e apresentam dados obtidos de sujeitos de $1^{\text {a }}$. à $4^{a}$. série (segundo à quinto ano do ensino fundamental). 
64

Para avaliação da habilidade de MTF foi utilizada a Prova de Memória de Trabalho Fonológica (HAGE; GRIVOL, 2009), que tem por objetivo avaliar o número de itens que cada criança consegue reter e recuperar da memória imediata após a apresentação verbal de uma lista de não palavras e dígitos. A pontuação obtida é calculada da seguinte forma: 2 pontos quando a repetição é correta na 1a vez, 1 ponto quando correta na $2^{\underline{a}}$ vez e 0 ponto quando não consegue nas duas primeiras tentativas. Para considerar a resposta adequada, a repetição deve ser idêntica a do avaliador, sendo permitido, ao avaliador, repetir apenas mais uma vez cada palavra. Conforme as normas de aplicação do teste, durante a repetição, trocas da vogal "e" por "i” em final de palavra, ou ainda, da vogal fechada "e/o" por aberta "é/ó" não foram considerados erros. 
5 Resultados 



\section{RESULTADOS}

$\mathrm{Na}$ tabela 4 são apresentados os desempenhos nas habilidades do processamento fonológico e a comparação entre os gêneros. Observa-se que não houve diferença estatisticamente significante entre meninos e meninas.

Tabela 4 - Desempenho obtido nas habilidades do processamento fonológico e comparação entre os gêneros

\begin{tabular}{|c|c|c|c|c|c|}
\hline $\begin{array}{l}\text { Habilidades do } \\
\text { Processamento } \\
\text { Fonológico }\end{array}$ & Resultado & $\begin{array}{l}\text { Total } \\
\text { n/ \% }\end{array}$ & $\begin{array}{c}\text { Meninas } \\
\mathrm{n} / \%\end{array}$ & $\begin{array}{l}\text { Meninos } \\
\text { n/ \% }\end{array}$ & $\begin{array}{c}\text { Valor de } \\
\qquad p^{\star}\end{array}$ \\
\hline \multirow{2}{*}{ Resultado CF } & Adequado-0 & $27 / 90 \%$ & $17 / 94 \%$ & $10 / 83 \%$ & \multirow{2}{*}{0,35} \\
\hline & Alterado-1 & $3 / 10 \%$ & $1 / 6 \%$ & $2 / 17 \%$ & \\
\hline \multirow{2}{*}{$\begin{array}{c}\text { Nomeação de } \\
\text { Objetos }\end{array}$} & Adequado & $29 / 97 \%$ & $17 / 94 \%$ & $12 / 100 \%$ & \multirow{2}{*}{0,60} \\
\hline & Alterado & $1 / 3 \%$ & $1 / 6 \%$ & $0 / 0 \%$ & \\
\hline \multirow{2}{*}{$\begin{array}{c}\text { Nomeação de } \\
\text { Cores }\end{array}$} & Adequado & $26 / 87 \%$ & $17 / 94 \%$ & $9 / 75 \%$ & \multirow{2}{*}{0,16} \\
\hline & Alterado & $4 / 13 \%$ & $1 / 6 \%$ & $3 / 25 \%$ & \\
\hline \multirow{2}{*}{$\begin{array}{c}\text { Nomeação de } \\
\text { Letras }\end{array}$} & Adequado & $27 / 90 \%$ & $16 / 89 \%$ & $11 / 92 \%$ & \multirow{2}{*}{0,65} \\
\hline & Alterado & $3 / 10 \%$ & $2 / 11 \%$ & $1 / 8 \%$ & \\
\hline \multirow{2}{*}{$\begin{array}{c}\text { Nomeação de } \\
\text { Dígitos }\end{array}$} & Adequado & $20 / 67 \%$ & $11 / 71 \%$ & $9 / 75 \%$ & \multirow{2}{*}{0,35} \\
\hline & Alterado & $10 / 33 \%$ & $7 / 29 \%$ & $3 / 25 \%$ & \\
\hline \multirow{2}{*}{$\begin{array}{c}\text { MT } \\
\text { Pseudopalavras }\end{array}$} & Adequado & $26 / 87 \%$ & $15 / 83 \%$ & $11 / 92 \%$ & \multirow{2}{*}{0,47} \\
\hline & Alterado & $4 / 13 \%$ & $3 / 17 \%$ & $1 / 8 \%$ & \\
\hline \multirow{2}{*}{$\begin{array}{l}\text { MT Dígitos } \\
\text { Ordem Direta }\end{array}$} & Adequado & $29 / 97 \%$ & $17 / 94 \%$ & $12 / 100 \%$ & \multirow{2}{*}{0,60} \\
\hline & Alterado & $1 / 3 \%$ & $1 / 6 \%$ & $0 / 0 \%$ & \\
\hline \multirow{2}{*}{$\begin{array}{c}\text { MT Dígitos } \\
\text { Ordem Inversa }\end{array}$} & Adequado & $25 / 83 \%$ & $16 / 89 \%$ & $9 / 75 \%$ & \multirow{2}{*}{0,30} \\
\hline & Alterado & $5 / 17 \%$ & $2 / 11 \%$ & $3 / 25 \%$ & \\
\hline \multirow{2}{*}{$\begin{array}{l}\text { MT Total } \\
\text { Dígitos }\end{array}$} & Adequado & $29 / 97 \%$ & $17 / 94 \%$ & $12 / 100 \%$ & \\
\hline & Alterado & $1 / 3 \%$ & $1 / 6 \%$ & $0 / 0 \%$ & \\
\hline
\end{tabular}

$\mathrm{Na}$ tabela 5 estão apresentados os resultados quanto a habilidades de compreensão leitora e a comparação entre os gêneros, e observou-se que não houve diferença estatística. Ressalta-se que as habilidades que tiveram mais dificuldades foram: relaciona as ideias $(63 \%)$, apresenta as ideias em lista $(53 \%)$, identifica organização com perguntas (87\%), relato com ajuda de perguntas $(67 \%)$, faz comentários (77\%), localiza erros de compreensão e usa recursos (57\%). 
Tabela 5 - Habilidades de compreensão leitora (após a leitura) e comparação entre os gêneros

\begin{tabular}{|c|c|c|c|c|c|}
\hline Depois da leitura & Resultado & $\begin{array}{l}\text { Total } \\
\mathrm{n} / \%\end{array}$ & $\begin{array}{l}\text { Meninas } \\
\mathrm{n} / \%\end{array}$ & $\begin{array}{l}\text { Meninos } \\
\mathrm{n} / \%\end{array}$ & $\begin{array}{l}\text { Valor } \\
\text { de } p^{\star}\end{array}$ \\
\hline \multirow{2}{*}{$\begin{array}{l}\text { Relato sem ajuda de } \\
\text { perguntas }\end{array}$} & Sim & $18 / 60$ & $10 / 56$ & $8 / 67$ & \multirow{2}{*}{0,41} \\
\hline & Não & $12 / 40$ & $8 / 44$ & $4 / 33$ & \\
\hline \multirow{2}{*}{$\begin{array}{l}\text { Relato com ajuda de } \\
\text { perguntas }\end{array}$} & Sim & $18 / 60$ & $8 / 44$ & $4 / 33$ & \multirow{2}{*}{0,41} \\
\hline & Não & $12 / 40$ & $10 / 56$ & $8 / 67$ & \\
\hline \multirow{2}{*}{ Relaciona as ideias } & Sim & $11 / 37$ & $4 / 22$ & $7 / 58$ & \multirow{2}{*}{0,52} \\
\hline & Não & $19 / 63$ & $14 / 78$ & $5 / 42$ & \\
\hline \multirow{2}{*}{ Apresenta as ideias em lista } & Sim & $14 / 47$ & $10 / 56$ & $4 / 33$ & \multirow{2}{*}{0,20} \\
\hline & Não & $16 / 53$ & $8 / 44$ & $8 / 67$ & \\
\hline \multirow{2}{*}{$\begin{array}{l}\text { Identifica organização } \\
\text { espontaneamente }\end{array}$} & Sim & $16 / 53$ & $8 / 44$ & $8 / 67$ & \multirow{2}{*}{0,20} \\
\hline & Não & $14 / 47$ & $10 / 56$ & $4 / 33$ & \\
\hline \multirow{2}{*}{$\begin{array}{c}\text { Identifica organização com } \\
\text { perguntas }\end{array}$} & Sim & $4 / 13$ & $2 / 11$ & $2 / 17$ & \multirow{2}{*}{0,53} \\
\hline & Não & $26 / 87$ & $16 / 89$ & $10 / 83$ & \\
\hline \multirow{2}{*}{$\begin{array}{l}\text { Conhecimento prévio sem } \\
\text { perguntas }\end{array}$} & Sim & $19 / 63$ & $11 / 61$ & $8 / 67$ & \multirow{2}{*}{0,53} \\
\hline & Não & $11 / 37$ & $7 / 39$ & $4 / 33$ & \\
\hline \multirow{2}{*}{$\begin{array}{l}\text { Conhecimento prévio com } \\
\text { perguntas }\end{array}$} & Sim & $10 / 33$ & $6 / 33$ & $4 / 33$ & \multirow{2}{*}{0,65} \\
\hline & Não & $20 / 67$ & $12 / 67$ & $8 / 67$ & \\
\hline \multirow{2}{*}{ Faz comentários } & Sim & $7 / 23$ & $3 / 17$ & $4 / 33$ & \multirow{2}{*}{0,26} \\
\hline & Não & $23 / 77$ & $15 / 83$ & $8 / 67$ & \\
\hline \multirow{2}{*}{$\begin{array}{c}\text { Localiza erros de } \\
\text { compreensão e usa recursos }\end{array}$} & Sim & $13 / 43$ & $6 / 33$ & $7 / 58$ & \multirow{2}{*}{0,16} \\
\hline & Não & $17 / 57$ & $12 / 67$ & $5 / 42$ & \\
\hline
\end{tabular}

* Teste de Mann-Whitney. Valor de $p$ considerado $<0,05$.

$\mathrm{Na}$ tabela 06 apresenta-se a correlação entre as habilidades de compreensão leitora com a consciência fonológica. A análise foi realizada a partir do itens Durante a Leitura e Depois da Leitura. Observou-se que as habilidades de leitura que tiveram uma correlação forte e estatisticamente significante Durante a leitura foram: localiza erros de compreensão e usa recursos, aproxima o texto dos olhos, salta linha ou repete linha, perde-se na linha, via fonológica, via lexical, leitura vacilante, leitura fluente, pontuação. Para as habilidades de leitura que tiveram uma correlação forte e estatisticamente significante Depois da leitura foram: relato sem ajuda de perguntas, relato com ajuda de perguntas, uso de conhecimento prévio para inferir sem perguntas, uso de conhecimento prévio para inferir com perguntas. 
Tabela 06- Correlação das habilidades de compreensão leitora com a consciência fonológica (CF)

\begin{tabular}{|c|c|c|c|c|c|c|c|c|c|c|c|c|c|c|c|c|c|}
\hline \multirow{2}{*}{\multicolumn{3}{|c|}{$\begin{array}{c}\text { Habilidades de compreensão } \\
\text { leitora }\end{array}$}} & \multicolumn{3}{|c|}{ Análise } & \multicolumn{2}{|c|}{ Adição } & \multicolumn{2}{|c|}{ Segmentação } & \multicolumn{2}{|c|}{ Subtração } & \multirow{2}{*}{ Substituição } & \multirow{2}{*}{$\begin{array}{l}\text { Recepção } \\
\text { de rimas }\end{array}$} & \multirow{2}{*}{$\begin{array}{c}\text { Rima } \\
\text { sequencial }\end{array}$} & \multirow{2}{*}{$\begin{array}{l}\text { Reversão } \\
\text { silábica }\end{array}$} & \multirow{2}{*}{$\begin{array}{l}\text { Imagem } \\
\text { articulatória }\end{array}$} & \multirow{2}{*}{ Total CF } \\
\hline & & & Inicial & Final & Medial & Sílabas & Fonemas & Frasal & Vocabu & Sílabas & Fonemas & & & & & & \\
\hline \multirow{24}{*}{ 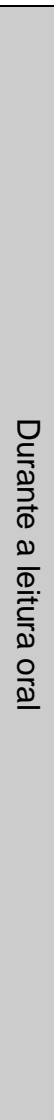 } & \multirow{2}{*}{ Salta ou repete linhas } & $r$ &.$^{a}$ & ,089 &,$- 695^{* *}$ &,$- 464^{* *}$ &,- 119 &,- 144 & ,050 &,$- 642^{* *}$ &,$- 486^{\star *}$ &,$- 693^{* *}$ &,- 356 &,- 105 &,- 231 &,$- 413^{*}$ &,$- 631^{* *}$ \\
\hline & & $p$ & . & ,640 &, 000 &, 010 &, 531 & ,448 & ,795 &, 000 &, 006 &, 000 & ,053 &, 581 & ,220 & ,023 &, 000 \\
\hline & \multirow{2}{*}{ Perde-se na linha } & r &.$^{a}$ &, 131 &,$- 473^{* *}$ &,- 288 &,- 175 &,- 211 & ,073 &,$- 398^{*}$ &,$- 379^{*}$ &,$- 588^{* *}$ &,- 196 &,- 010 &,- 180 &,- 193 &,$- 424^{*}$ \\
\hline & & $p$ & . & ,491 &, 008 &, 122 & ,356 & ,263 & ,702 & ,029 & ,039 &, 001 & ,299 & ,960 & ,342 & ,307 & ,020 \\
\hline & \multirow{2}{*}{ Via fonológica } & $r$ &.$^{a}$ & ,218 &,- 284 &,- 117 &,$- 534^{* *}$ &,- 132 & ,122 &,- 295 &,- 199 &,$- 502^{\star *}$ &,- 267 &,- 043 &,- 329 &,- 245 &,$- 452^{*}$ \\
\hline & & $p$ & . & ,247 &, 129 &, 539 &, 002 & ,486 &, 522 &, 113 & ,293 &, 005 &, 154 & ,822 & ,075 & ,191 &, 012 \\
\hline & \multirow{2}{*}{ Via lexical } & $r$ & $a^{a}$ &,- 218 & ,284 &, 117 &, $534^{* *}$ & , 132 &,- 122 & ,295 & ,199 &, $502^{\star *}$ & ,267 &, 043 & ,329 & ,245 &, $452^{*}$ \\
\hline & & $p$ & . & ,247 & ,129 &, 539 & ,002 & , 486 &, 522 & ,113 & ,293 & ,005 & ,154 & ,822 & ,075 & , 191 &, 012 \\
\hline & \multirow{2}{*}{ Leitura vacilante } & $r$ & $a^{a}$ & ,218 &,- 284 &,- 117 &,$- 534^{* *}$ &,- 132 & ,122 &,- 295 &,- 199 &,$- 502^{\star *}$ &,- 267 &,- 043 &,- 329 &,- 245 &,$- 452^{*}$ \\
\hline & & $p$ & . & ,247 & ,129 &, 539 &, 002 & ,486 &, 522 &, 113 & ,293 &, 005 &, 154 & ,822 & ,075 & ,191 & ,012 \\
\hline & \multirow{2}{*}{ Leitura fluente } & $r$ & $a^{a}$ &,- 218 & ,284 & ,117 &, $534^{\star *}$ & , 132 &,- 122 & ,295 & ,199 &, $502^{* *}$ & ,267 & ,043 & ,329 & ,245 &, $452^{*}$ \\
\hline & & $p$ & . & ,247 & , 129 &, 539 &, 002 & ,486 &, 522 & ,113 & ,293 & ,005 & ,154 & ,822 & ,075 & ,191 & ,012 \\
\hline & \multirow{2}{*}{ Pontuação } & r &.$^{a}$ & ,218 &,- 284 &,- 117 &,$- 534^{* *}$ &,- 132 & ,122 &,- 295 &,- 199 &,$- 502^{* *}$ &,- 267 &,- 043 &,- 329 &,- 245 &,$- 452^{*}$ \\
\hline & & $p$ & . & ,247 & ,129 &, 539 &, 002 & ,486 &, 522 &, 113 & ,293 &, 005 & ,154 & ,822 & ,075 & ,191 & ,012 \\
\hline & \multirow{2}{*}{ Tom e volume } & r &.$^{a}$ &, 062 & $-1,000^{* *}$ &,$- 695^{* *}$ &,- 171 &,- 287 & ,034 &,$- 617^{* *}$ &,$- 760^{* *}$ &,$- 685^{* *}$ &,$- 557^{* *}$ &,- 073 &,- 160 & ,104 &,$- 583^{* *}$ \\
\hline & & $p$ & . & ,745 &, 000 &, 000 & ,366 & ,124 & ,856 &, 000 &, 000 &, 000 &, 001 & ,702 & ,398 & ,583 &, 001 \\
\hline & \multirow{2}{*}{$\begin{array}{l}\text { Substitui letras ou } \\
\text { palavras }\end{array}$} & $r$ & ${ }^{a}$ & ,201 & ,112 & ,161 &,- 340 &,- 172 & ,112 & ,084 & ,017 & ,088 &,- 050 &,- 126 &,- 033 & ,233 & ,020 \\
\hline & & $p$ & . & ,287 &, 556 & ,395 & ,066 & ,362 &, 556 & ,661 & ,928 & ,643 & ,792 &, 508 & ,865 & ,215 & ,916 \\
\hline & \multirow{2}{*}{$\begin{array}{c}\text { Omite sílabas ou } \\
\text { palavras }\end{array}$} & $r$ &.$^{a}$ &.$^{a}$ &.$^{a}$ &.$^{a}$ &.$^{a}$ &.$^{a}$ &.$^{a}$ &.$^{a}$ &.$^{a}$ &.$^{a}$ &.$^{a}$ &.$^{a}$ &.$^{a}$ &.$^{a}$ &.$^{a}$ \\
\hline & & $p$ & . & . & . & . & . & & & - & . & . & . & . & . & . & \\
\hline & \multirow{2}{*}{$\begin{array}{l}\text { Acrescenta sílaba ou } \\
\text { palavras }\end{array}$} & $r$ &.$^{a}$ & ,062 & ,034 & ,050 &,- 171 &,- 287 & ,034 & ,069 &,- 127 & ,129 & ,062 &,- 073 &,- 160 & ,104 &,- 045 \\
\hline & & $p$ & . & ,745 & ,856 & ,795 & ,366 & ,124 & ,856 & ,719 &, 505 & ,497 & ,745 & ,702 & ,398 & ,583 & ,811 \\
\hline & \multirow{2}{*}{$\begin{array}{c}\text { Transpõe sílabas ou } \\
\text { palavras }\end{array}$} & $r$ &.$^{a}$ & ,111 &,$- 557^{* *}$ &,- 356 &,- 201 &,- 291 & ,062 &,$- 492^{* *}$ &,$- 480^{* *}$ &,$- 499^{* *}$ &,$- 630^{* *}$ & ,033 & ,072 & ,187 &,- 354 \\
\hline & & $p$ & . & ,559 & ,001 & ,053 & 286 & ,118 & ,745 & ,006 & ,007 &, 005 & ,000 & ,864 & ,706 & ,322 & ,055 \\
\hline
\end{tabular}




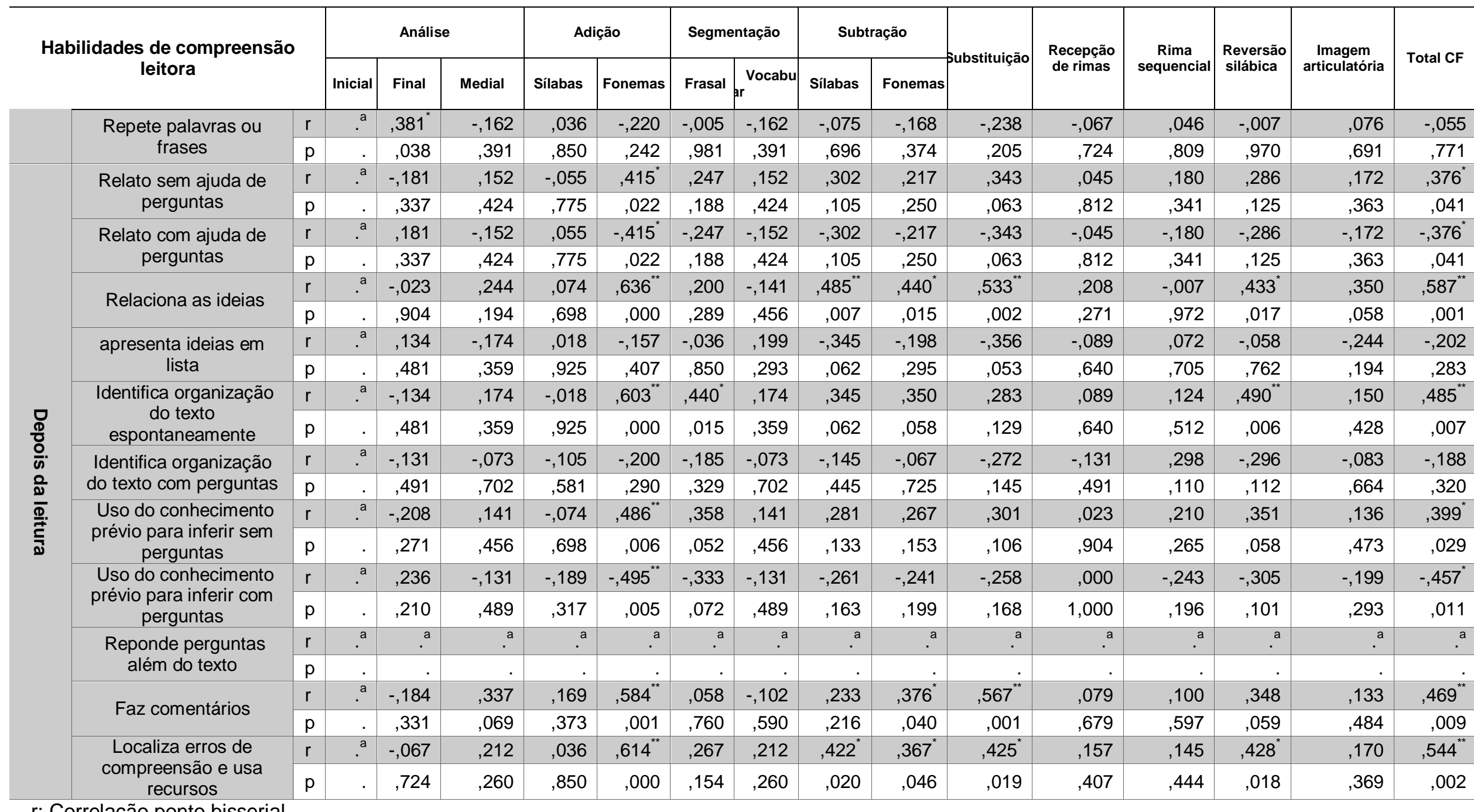

r: Correlação ponto bisserial

a: Não houve variação na variável e, portanto, não foi possível verificar a correlação.

* Correlação estatisticamente significante 
Referente a correlação da velocidade de leitura com a consciência fonológica representada na tabela 7 identificou-se uma correlação forte e estatisticamente significativa entre o tempo de leitura silenciosa com a adição de fonemas, o número de palavras por minuto da leitura silenciosa com adição de fonemas, tempo de leitura oral com análise final e adição de fonemas e o número de palavras por minuto da leitura oral com análise e adição de fonemas.

Tabela 7 - Correlação das habilidades da velocidade de leitura com a consciência fonológica (CF)

\begin{tabular}{|c|c|c|c|c|c|c|c|c|c|c|c|c|c|c|c|c|}
\hline \multirow{2}{*}{\multicolumn{2}{|c|}{$\begin{array}{l}\text { Habilidades da } \\
\text { velocidade de leitura }\end{array}$}} & \multicolumn{3}{|c|}{ Análise } & \multicolumn{2}{|c|}{ Adição } & \multicolumn{2}{|c|}{ Segmentação } & \multicolumn{2}{|c|}{ Subtração } & \multirow{3}{*}{$\begin{array}{r}\text { Substituição } \\
-, 321 \\
\end{array}$} & \multirow{3}{*}{$\begin{array}{r}\begin{array}{c}\text { Recepção } \\
\text { de rimas }\end{array} \\
-, 282\end{array}$} & \multirow{3}{*}{$\begin{array}{c}\begin{array}{c}\text { Rima } \\
\text { sequencial }\end{array} \\
-, 010\end{array}$} & \multirow{3}{*}{$\begin{array}{r}\begin{array}{c}\text { Reversão } \\
\text { silábica }\end{array} \\
\text {-,283 }\end{array}$} & \multirow{3}{*}{$\begin{array}{r}\begin{array}{c}\text { Imagem } \\
\text { articulatória }\end{array} \\
-, 009\end{array}$} & \multirow{3}{*}{$\begin{array}{c}\begin{array}{c}\text { Total } \\
\text { CF }\end{array} \\
-, 312 \\
\end{array}$} \\
\hline & & \multirow{2}{*}{$\begin{array}{c}\text { Inicial } \\
a \\
\end{array}$} & \multirow{2}{*}{$\begin{array}{l}\text { Final } \\
\text { 205 }\end{array}$} & \multirow{2}{*}{\begin{tabular}{|c|} 
Medial \\
,- 268
\end{tabular}} & \multirow{2}{*}{\begin{tabular}{|c|} 
Sílabas \\
,- 077 \\
\end{tabular}} & \multirow{2}{*}{$\begin{array}{r}\text { Fonemas } \\
, 374^{*}\end{array}$} & \multirow{2}{*}{$\begin{array}{r}\text { Frasal } \\
-352 \\
\end{array}$} & \multirow{2}{*}{\begin{tabular}{|c|} 
Vocabular \\
,- 161
\end{tabular}} & \multirow{2}{*}{$\begin{array}{l}\text { Sílabas } \\
-, 237\end{array}$} & \multirow{2}{*}{$\begin{array}{c}\text { Fonemas } \\
-, 350\end{array}$} & & & & & & \\
\hline $\begin{array}{l}\text { Tempo da leitura } \\
\text { silenciosa }\end{array}$ & $r$ & & & & & & & & & & & & & & & \\
\hline (segundos) & $p$ & a. & ,276 & , 152 & ,685 &, 042 &, 056 & ,396 & ,208 &, 058 & ,084 & , 130 & ,960 & , 130 & ,962 & ,094 \\
\hline \multirow{2}{*}{$\begin{array}{l}\mathrm{N}^{\circ} \text { de palavras por } \\
\text { minuto da leitura } \\
\text { silenciosa }\end{array}$} & $r$ & a. & ,244 & ,268 & ,062 &, $377^{*}$ & ,332 & ,161 & ,214 & ,322 & ,279 & ,270 & ,072 & ,234 &,- 040 & ,280 \\
\hline & $p$ & $\mathrm{a}$. & ,194 & , 152 & ,746 & ,040 & ,073 & ,396 & ,256 & ,083 & ,135 & , 150 & ,704 & ,214 & ,833 & , 133 \\
\hline \multirow{2}{*}{$\begin{array}{l}\text { Tempo da leitura oral } \\
\text { (segundos) }\end{array}$} & $r$ & a. &, $392^{*}$ &,- 290 &,- 039 &, $434^{*}$ & ,282 &,- 204 &,- 329 &,- 350 &,- 351 &,- 218 &,- 058 &,- 268 & ,012 &,- 295 \\
\hline & $p$ & $\mathrm{a}$. & ,032 & , 120 & ,839 &, 016 & ,131 & ,280 & ,076 & ,058 & ,057 & ,246 & ,760 & , 152 & ,948 & ,114 \\
\hline \multirow{2}{*}{$\begin{array}{l}\mathrm{N}^{\circ} \text { de palavras por } \\
\text { minuto da leitura oral }\end{array}$} & $r$ & a. & $385^{*}$ & ,279 & ,031 &, $431^{*}$ & ,277 & ,204 & ,323 & ,345 & ,357 & ,212 & ,055 & ,269 &,- 007 & ,296 \\
\hline & $\mathrm{p}$ & a. & ,035 & , 135 & ,871 & ,017 & , 138 & ,280 & ,082 & ,062 & ,053 & ,261 & ,772 & , 150 & ,969 & ,112 \\
\hline
\end{tabular}

r: Correlação de Spearman

a: Não houve variação na variável e, portanto, não foi possível verificar a correlação.

* Correlação estatisticamente significante

$\mathrm{Na}$ tabela 8 quanto à correlação das habilidades de compreensão leitora com a memória de trabalho fonológica verificou-se uma correlação forte e significativa para o item DURANTE A LEITURA em: apoio articulatório e pseudopalavras (2 e 5 sílabas), perde-se na linha e pseudopalavras (5 sílabas) substitui letras e palavras com pseudopalavras (5 sílabas), transpõe 
sílabas ou palavras com pseudopalavra (5 sílabas), repete palavras ou frase com pseudopalvras (2, 3, 4 e 5 sílabas). Ainda via fonólogica, via lexical, leitura vacilante, leitura fluente, pontuação, substitui letras ou palavras, transpõe sílabas ou palavras com dígitos de ordem direta. Considerando o item DEPOIS DA LEITURA obteve-se correlação forte e significância estatística em Identifica organização do texto espontaneamente com pseudopalavras (2 sílabas) e com dígitos de ordem direta.

Tabela 8- Correlação das habilidades de compreensão leitora com a memória de trabalho fonológica

\begin{tabular}{|c|c|c|c|c|c|c|c|c|c|}
\hline \multicolumn{10}{|c|}{ Habilidades da Compreensão Leitora } \\
\hline \multirow{24}{*}{ 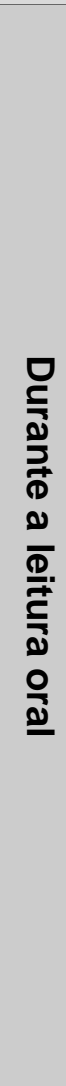 } & \multirow{2}{*}{ Apoio articulatório } & $\boldsymbol{f}$ &,$- 380^{*}$ &,- 109 &,- 047 &,$- 453^{*}$ &,$- 385^{\star}$ &,$- 563^{\star \star}$ &,- 275 \\
\hline & & p & ,038 &, 567 &, 804 & ,012 & ,036 & ,001 &, 141 \\
\hline & \multirow{2}{*}{ Salta ou repete linhas } & $r$ &,$- 449^{*}$ &,- 290 & ,052 &,- 015 &,- 113 &, 005 &,- 031 \\
\hline & & $\mathrm{p}$ &, 013 & ,121 & ,787 & ,938 &, 551 & ,977 &, 871 \\
\hline & \multirow{2}{*}{ Perde-se na linha } & $r$ &,- 247 &,- 071 &,- 279 &,$- 513^{* *}$ &,$- 503^{* *}$ &,- 351 &,- 142 \\
\hline & & $p$ &, 188 &, 710 & ,136 &, 004 & ,005 &, 057 & ,453 \\
\hline & \multirow{2}{*}{ Via fonológica } & $r$ &,- 336 &,- 053 &,- 268 &,- 361 &,$- 415^{\star}$ &,$- 386^{*}$ &,- 193 \\
\hline & & $p$ & ,069 & ,783 & ,152 &, 050 & ,023 & ,035 & ,307 \\
\hline & \multirow{2}{*}{ Via lexical } & $r$ & ,336 & ,053 & ,268 & ,361 &, $415^{*}$ &, $386^{*}$ & ,193 \\
\hline & & $p$ & ,069 & ,783 & ,152 &, 050 &, 023 &, 035 & ,307 \\
\hline & \multirow{2}{*}{ Leitura vacilante } & $r$ &,- 336 &,- 053 &,- 268 &,- 361 &,$- 415^{*}$ &,$- 386^{*}$ &,- 193 \\
\hline & & $p$ & ,069 &, 783 & ,152 &, 050 & ,023 & ,035 & ,307 \\
\hline & \multirow{2}{*}{ Leitura fluente } & $r$ & ,336 & ,053 & ,268 & ,361 &, $415^{*}$ &, $386^{*}$ & ,193 \\
\hline & & $p$ &, 069 & ,783 & ,152 &, 050 & ,023 &, 035 & ,307 \\
\hline & \multirow{2}{*}{ Pontuação } & $r$ &,- 336 &,- 053 &,- 268 &,- 361 &,$- 415^{*}$ &,$- 386^{*}$ &,- 193 \\
\hline & & $\mathrm{p}$ &, 069 & ,783 & ,152 &, 050 & ,023 & ,035 & ,307 \\
\hline & \multirow{2}{*}{ Tom e volume } & $r$ & ,078 & ,134 &,- 031 &,- 114 &,- 047 & ,004 &,- 228 \\
\hline & & $p$ & ,682 & ,480 & ,869 &, 549 & ,806 & ,984 & ,225 \\
\hline & \multirow{2}{*}{ Substitui letras ou palavras } & $r$ &, 095 & ,163 &,- 265 &,$- 369^{*}$ &,- 307 &,$- 471^{\star *}$ &,- 070 \\
\hline & & $p$ & ,618 & ,388 &, 157 &, 044 &, 098 &, 009 & ,714 \\
\hline & \multirow{2}{*}{ Omite sílabas ou palavras } & $r$ &.$^{a}$ &.$^{a}$ &.$^{\mathrm{a}}$ &.$^{a}$ &.$^{a}$ &.$^{a}$ &.$^{\mathrm{a}}$ \\
\hline & & $p$ & & & & & & & \\
\hline & \multirow{2}{*}{ Acrescenta sílaba ou palavras } & $\mathrm{r}$ & ,078 & ,134 &,- 300 & ,093 &,- 047 &,- 223 & ,048 \\
\hline & & $p$ & ,682 & ,480 & ,107 & ,625 & ,806 & ,236 & ,803 \\
\hline
\end{tabular}




\begin{tabular}{|c|c|c|c|c|c|c|c|c|c|}
\hline & \multirow{2}{*}{ Transpõe sílabas ou palavras } & $r$ & , 140 & ,241 &,- 217 &,$- 576^{* *}$ &,$- 390^{*}$ &,$- 434^{\star}$ &,- 272 \\
\hline & & $p$ & ,461 & ,200 & ,250 &, 001 &, 033 &, 017 &, 145 \\
\hline & \multirow{2}{*}{ Repete palavras ou frases } & r &,$- 367^{\star}$ &,$- 389^{*}$ &,$- 533^{* *}$ &,$- 438^{*}$ &,$- 658^{* *}$ &,- 223 & , 143 \\
\hline & & $p$ &, 046 & ,034 &, 002 &, 015 &, 000 & ,236 & ,452 \\
\hline \multirow{22}{*}{$\begin{array}{l}\frac{\square}{\Phi} \\
\frac{\Phi}{8} \\
\frac{0}{6} . \\
\frac{0}{0} \\
\frac{\bar{D}}{\bar{D}} \\
\frac{\bar{E}}{\bar{D}}\end{array}$} & \multirow{2}{*}{ Relato sem ajuda de perguntas } & r & ,343 & ,221 & , 108 & ,258 & ,309 & ,224 & , 142 \\
\hline & & $p$ & ,064 & ,240 &, 569 &, 169 & 097 & ,233 & ,456 \\
\hline & \multirow{2}{*}{ Relato com ajuda de perguntas } & r &,- 343 &,- 221 &,- 108 &,- 258 &,- 309 &,- 224 &,- 142 \\
\hline & & $p$ &, 064 & ,240 &, 569 &, 169 & ,097 & ,233 &, 456 \\
\hline & \multirow[t]{2}{*}{ Relaciona as ideias } & r &, 116 & ,075 & ,228 & ,274 & ,311 & ,132 & 045 \\
\hline & & $p$ &, 541 & ,694 & ,225 &, 144 &, 095 & ,486 & ,813 \\
\hline & \multirow{2}{*}{ Apresenta ideias em lista } & r & ,028 &,- 072 &,- 132 & ,015 &,- 063 & ,205 & ,241 \\
\hline & & $p$ & ,883 & ,704 & ,487 & ,938 & ,742 & ,276 & ,200 \\
\hline & \multirow{2}{*}{ Identifica organização do texto espontaneamente } & r & ,393 & 072 & ,132 & ,208 & ,269 & $366^{*}$ & ,190 \\
\hline & & $p$ & ,032 & ,704 & ,487 & ,269 & , 150 &, 047 & ,315 \\
\hline & \multirow{2}{*}{ Identifica organização do texto com perguntas } & r &,- 165 & 071 &,- 005 & , 186 & ,099 & 022 & , 167 \\
\hline & & $p$ & ,384 & ,710 &, 980 & ,326 & 603 & ,908 & ,378 \\
\hline & \multirow{2}{*}{$\begin{array}{l}\text { Uso do conhecimento prévio para inferir sem } \\
\text { perguntas }\end{array}$} & r & ,320 & , 175 & ,222 & ,227 & ,331 & ,311 & , 126 \\
\hline & & $p$ &, 085 & ,355 & ,239 & ,227 &, 074 &, 094 &, 506 \\
\hline & \multirow{2}{*}{$\begin{array}{l}\text { Uso do conhecimento prévio para inferir com } \\
\text { perguntas }\end{array}$} & $r$ &,- 297 &,- 128 &,- 187 &,- 197 &,- 284 &,- 252 &,- 181 \\
\hline & & $p$ &, 111 &, 501 & ,321 & ,297 & ,129 & ,179 & ,339 \\
\hline & \multirow{2}{*}{ Reponde perguntas além do texto } & $r$ &.$^{a}$ &.$^{a}$ &.$^{a}$ &.$^{a}$ &.$^{\mathrm{a}}$ &.$^{\mathrm{a}}$ & ${ }^{\mathrm{a}}$ \\
\hline & & $p$ & . & & . & & & . & \\
\hline & \multirow{2}{*}{ Faz comentários } & $r$ & ,265 & ,313 & ,150 &,- 013 & ,166 & ,133 & ,191 \\
\hline & & $p$ & ,157 & ,092 & ,429 &, 945 & ,380 & ,483 &, 313 \\
\hline & \multirow{2}{*}{ Localiza erros de compreensão e usa recursos } & r & ,339 & 097 & ,196 & ,199 & ,290 & ,290 &, $376^{*}$ \\
\hline & & $p$ & ,067 & ,609 & ,299 & ,293 & ,120 & ,120 &, 041 \\
\hline
\end{tabular}

r: Correlação ponto bisserial

a: Não houve variação na variável e, portanto, não foi possível verificar a correlação.

* Correlação estatisticamente significante 
$\mathrm{Na}$ tabela 9 quanto à correlação das habilidades de velocidade de leitura com a memória de trabalho fonológica destaca-se correlação forte e estatisticamente significante em: Tempo da leitura silenciosa com pseudopalavras ( 5 sílabas) e dígitos em ordem direta, número de palavras por minuto da leitura silenciosa com pseudopalavras ( 5 sílabas), Tempo da leitura oral (segundos) com pseudopalavras ( 5 sílabas) e dígitos em ordem direta, número de palavras por minuto da leitura oral com pseudopalavras (5 sílabas) e dígitos em ordem direta

Tabela 9 - Correlação das habilidades da velocidade de leitura com a memória de trabalho fonológica

\begin{tabular}{|c|c|c|c|c|c|c|c|c|c|}
\hline \multirow{2}{*}{\multicolumn{2}{|c|}{ Habilidades da velocidade de leitura }} & \multicolumn{5}{|c|}{ Pseudopalavras } & \multicolumn{3}{|c|}{ Dígitos } \\
\hline & & 2 Sílabas & 3 Sílabas & 4 Sílabas & 5 Sílabas & Total & Ordem direta & Ordem inversa & Total \\
\hline \multirow{2}{*}{ Tempo da leitura silenciosa (segundos) } & r &,- 258 & 045 &,- 265 &,$- 569^{* *}$ &,$- 463^{\star *}$ &,$- 434^{\star}$ &,- 215 & \\
\hline & $\mathrm{p}$ & ,169 & ,815 & ,157 &, 001 &, 010 &, 017 & ,253 & \\
\hline \multirow{2}{*}{$\mathbf{N}^{\circ}$ de palavras por minuto da leitura silenciosa } & r & ,246 &,- 078 & 209 &, $538^{* *}$ &, $413^{*}$ &, $466^{* *}$ & 279 & \\
\hline & $\mathrm{p}$ & ,189 &, 681 & ,267 & ,002 &, 023 &, 009 & ,136 & \\
\hline \multirow{2}{*}{ Tempo da leitura oral (segundos) } & $r$ &,- 332 & ,001 &,- 281 &,$- 486^{* *}$ &,$- 481^{\star \star}$ &,$- 401^{*}$ &,- 187 & \\
\hline & $\mathrm{p}$ & ,073 & ,995 & ,133 & ,007 &, 007 & ,028 & ,323 & \\
\hline \multirow{2}{*}{$\mathrm{N}^{\circ}$ de palavras por minuto da leitura oral } & $r$ & ,327 &,- 001 & 284 &, $482^{* *}$ &, $480^{* *}$ &, $396^{\star}$ & 182 & \\
\hline & $\mathrm{p}$ & ,078 & ,995 & 129 &, 007 & ,007 & ,030 & ,335 & \\
\hline
\end{tabular}

r: Correlação ponto bisserial

: Não houve variação na variável e, portanto, não foi possível verificar a correlação.

* Correlação estatisticamente significante 


\subsection{ANÁLISE DOS RESULTADOS}

Os resultados foram analisados estatisticamente por meio de testes de correlação paramétricos ou não paramétricos, de acordo com a distribuição dos resultados. Dessa forma, os dados referentes à consciência fonológica, acesso ao léxico e memória de trabalho fonológica foram correlacionados com a compreensão leitora. A descrição da amostra foi feita em valores de média, mediana, mínimo e máximo. Para a análise comparativa entre os grupos foi utilizado o Teste de MannWhitney. Foi adotado o nível de significância de 5\% (0,050). O grau de correlação entre as variáveis de interesse foi verificado pela Análise de Correlação de Spearman. 

6 Discussão 



\section{DISCUSSÃO}

Muitas vezes, no contexto escolar, observam-se adolescentes que apresentam certa fluência ao ler, mas não sabem compreender a análise de questões referentes a um texto proposto, por exemplo. $O$ hábito da leitura é de extrema importância ao indivíduo, pois ativa o raciocínio e o senso crítico, desenvolve a imaginação, propicia o acesso a novos conhecimentos e culturas e aumenta o vocabulário. Deve ser despertado na infância a fim de que se aprimore ao longo dos anos.

Diante de tais fatos, este estudo apresentou as características de compreensão leitora de adolescentes e dos aspectos subjacentes à leitura (processamento fonológico), visando o melhor entendimento dos professores que trabalham com a habilidade leitora desta população, e, ainda, propõe um programa de intervenção das habilidades de compreensão leitora.

Para GERMANO E CAPELLINI (2017), a compreensão da leitura realizada de modo competente torna-se, portanto, o objetivo final da aprendizagem da leitura. Entretanto, diversos fatores concorrem para que a compreensão de textos se realize, porém são insuficientes para, de forma isolada, determiná-la. Têm especial atenção os fatores linguísticos, tais como o processamento fonológico que ancora a capacidade de decodificar, o vocabulário e o conhecimento sintático indispensáveis na compreensão; os fatores cognitivos memória de trabalho, monitoramento e a capacidade de estabelecer inferências, bem como os fatores sociais, que envolvem as circunstâncias em que a leitura ocorre (contexto social, objetivos, motivações e expectativas do leitor), e os conhecimentos prévios do leitor, adquiridos através de sua vivência sociocultural. Dentre essas, as habilidades metalinguísticas de consciência fonológica mostram-se preditoras do desenvolvimento da leitura, pois, ao início da alfabetização, o escolar precisa desenvolver sensibilidade à estrutura interna das palavras, ou seja, deve ser capaz de identificar e manipular fonemas e sílabas, para assim posteriormente decodificálas.

A partir da análise dos resultados deste estudo observou-se que não houve diferença estatisticamente significante quando se comparou o desempenho nas habilidades do processamento fonológico entre meninos e meninas. 
80

Há na literatura várias pesquisas envolvendo a variável gênero, relacionada às diferenças anatômicas e funcionais do cérebro; desvios fonológicos desenvolvimento da linguagem aprendizagem, e dificuldades de aprendizagem, evidenciando diferenças importantes. Porém, são escassas as pesquisas que consideram a variável gênero e a CF como foco principal da investigação.

Em estudos (Moura, 2008, Cielo et. al, 2010) foi verificado que meninas possuem maior habilidade para analisar pequenos segmentos, já os meninos desempenharam melhor as tarefas de análise com palavras.

$\mathrm{Na}$ pesquisa desenvolvida por Flores-Mendoza et.al (2007), meninos e meninas da mesma série apresentaram desempenhos semelhantes nas atividades avaliadas sugerindo não haver influência do gênero no desempenho escolar em escrita, leitura e aritmética e nas habilidades do processamento fonológico, nas séries iniciais do EF. Resultado este corrobora com o presente estudo.

Ao se comparar as habilidades de compreensão leitora entre meninos e meninas também não foi evidenciada diferença estatisticamente significativa. Santos e Fernandes (2016) em seu estudo após a verificação de valor preditivo de testes de compreensão de leitura e de avaliação de escrita para o desempenho escolar, os quesitos gênero e ano escolar foram integrados para a investigação de possíveis diferenças entre as crianças. Ao analisar as duas variáveis simultaneamente, os resultados apontaram não haver interação entre elas. Também não foi significativa a diferença entre os gêneros em nenhuma prova, mas pode-se observar que o teste Cloze foi o que apresentou maior diferença com melhor performance das meninas. Essa diferença em relação ao Cloze, no entanto, é apontada como significativa na literatura.

Resultado semelhante foi encontrado por Piovezan e Castro (2008), quando em seu estudo encontrou que as correlações entre a compreensão em leitura com a idade e série foram positivas e baixas, ou seja, as séries mais avançadas e os alunos mais velhos alcançaram melhores pontuações no teste Cloze quando comparados com as séries menos avançadas e os alunos mais jovens. No entanto, os resultados quanto ao gênero foram divergentes com a literatura, pois as meninas apresentaram nível mais baixo de compreensão do que os meninos, enquanto a revisão de literatura apresenta resultados contrários (Joly, 2006; Oliveira $\&$ cols, 2007). 
A função de compreender um texto e seus pormenores, o uso de palavras e expressões em seu contexto requer a habilidade de leitura e escrita. Para tal finalidade, os profissionais da educação e comunicação procuram desenvolver atividades ou estratégias de leitura para auxiliar a compreensão leitora entre crianças e adolescentes. Estratégias de leitura são técnicas ou métodos que os leitores usam para adquirir a informação, ou ainda procedimentos ou atividades escolhidas para facilitar o processo de compreensão em leitura. São planos flexíveis adaptados às diferentes situações que variam de acordo com o texto a ser lido e a abordagem elaborada previamente pelo leitor para facilitar a sua compreensão (DUFFY\& cols., 1987; BROWN, 1994; PELLEGRINI, 1996; KOPKE, 2001).

Além disso, a utilização de estratégias de leitura compreende três momentos: o antes, o durante e o após a leitura. Na pré-leitura, é feita uma análise global do texto (do título, dos tópicos e das figuras/gráficos), predições e também o uso do conhecimento prévio. Durante a leitura é feita uma compreensão da mensagem passada pelo texto, uma seleção das informações relevantes, uma relação entre as informações apresentadas no texto e uma análise das predições feitas antes da leitura, para confirmá-las ou refutá-las. Depois da leitura é feita uma análise com o objetivo de rever e refletir sobre o conteúdo lido, ou seja, a importância da leitura, o significado da mensagem, a aplicação para solucionar problemas e a verificação de diferentes perspectivas apresentadas para o tema. Também é realizada uma discussão da leitura, com expressão e comunicação do conteúdo lido após análise e reflexão, seguida de um resumo e de uma releitura do texto (KOPKE, 1997; DUKE\& PEARSON, 2002).

Neste estudo verificou-se a correlação de compreensão leitora com a consciência fonológica e a memória de trabalho fonológica em dois momentos, durante a leitura e após a leitura.

Observou-se que as habilidades de leitura que tiveram uma correlação forte e estatisticamente significante. Durante a leitura foram: localiza erros de compreensão e usa recursos, aproxima o texto dos olhos, salta linha ou repete linha, perde-se na linha, via fonológica, via lexical, leitura vacilante, leitura fluente, pontuação. Para as habilidades de leitura que tiveram uma correlação forte e estatisticamente significante Depois da leitura foram: relato sem ajuda de perguntas, 
relato com ajuda de perguntas, uso de conhecimento prévio para inferir sem perguntas, uso de conhecimento prévio para inferir com perguntas.

As habilidades metalinguísticas de consciência fonológica mostram-se preditoras do desenvolvimento da leitura, pois, ao início da alfabetização, o escolar precisa desenvolver sensibilidade à estrutura interna das palavras, ou seja, deve ser capaz de identificar e manipular fonemas e sílabas, para assim posteriormente decodificá-las

Acredita-se que exista uma relação entre essas habilidades com decodificação, a fluência e a compreensão de leitura. Ainda para UVO, Germano e Capellini, (2017) há relação direta entre a decodificação e a compreensão; de acordo com os autores, dificuldades encontradas na decodificação resultariam, como consequência, dificuldades de compreensão leitora. Sendo assim, após adquirir as habilidades metalinguísticas, o escolar será capaz de realizar a conversão de símbolos gráficos em som, decodificando-os e realizando 0 reconhecimento das palavras. A compreensão baseia-se no conhecimento dessas habilidades, mas também no conhecimento do vocabulário, processo de reconhecimento sintático, fluência de leitura e na capacidade de fazer inferências, além de atenção, memória, compreensão da linguagem falada e as funções executivas (planejamento, organização, controle de informação).

Recente estudo de Santos e Ferraz, (2017) relata que quanto à relação entre a compreensão de leitura e a consciência fonológica, foi detectada uma correlação de magnitude fraca. Este achado é congruente com o de estudo anterior, realizado por Mota e Santos (2009), o qual identificou correlações fracas e moderadas entre a compreensão de leitura e a consciência fonológica (rima e aliteração), aferidas, respectivamente, por dois textos do teste de Cloze e as Tarefas de Consciência Fonológica em alunos $(\mathrm{N}=42)$ do primeiro ciclo do Fundamental ( $1^{\text {a }} \mathrm{e}$ $2^{\mathrm{a}}$ séries).

Ao que se refere à correlação da velocidade de leitura com a consciência fonológica identificou-se neste estudo uma correlação forte e estatisticamente significativa entre o tempo de leitura silenciosa com a adição de fonemas, o número de palavras por minuto da leitura silenciosa com adição de fonemas, tempo de leitura oral com análise final e adição de fonemas e o número de palavras por minuto da leitura oral com análise e adição de fonemas 
A leitura pode ser avaliada de forma silenciosa e oral, sendo necessária nesta última uma codificação fonológica e articulatória, dificultando o acesso direto ao input visual. A avaliação da velocidade de leitura fornece dados sobre elementos utilizados pelo indivíduo durante $\mathrm{o}$ ato para serem analisados, como decodificação dos grafemas, reconhecimento instantâneo, global e parcial, nível de leitura. Um estudo sobre velocidade de leitura informa que o input auditivo durante a leitura oral permitiu melhor compreensão do texto ao se comparar com a leitura silenciosa (Cunha e Capellini, 2016).

Os achados dessa pesquisa demonstram a existência de uma correlação entre as habilidades em consciência fonológica e a velocidade. Os escolares que apresentaram maior habilidade na manipulação dos sons da fala conseguiram desenvolver velocidade de leitura de maneira mais eficiente. Em trabalho publicado por Barrera e Maluf (2003), esse aspecto ficou evidenciado, pois a consciência fonológica foi a habilidade que mais apresentou influência no desenvolvimento da linguagem escrita, desempenhando um papel facilitador, de forma a permitir que a leitura se desenvolvesse de maneira potencializada nas crianças com melhores índices de consciência fonológica. Outro estudo, Capovilla et.al (2004), refere que na consciência fonológica a habilidade fonêmica influencia mais no desempenho da leitura e escrita do que a habilidade silábica, o que corrobora os achados dessa pesquisa em que o maior escore de erros foi no nível fonêmico da consciência fonológica.

A fluência e a agilidade na leitura, elementos que compõem o reconhecimento de palavras, contribuem com a compreensão do que é lido, principalmente nas crianças matriculadas nos anos escolares iniciais. No entanto, é necessário salientar que o reconhecimento de palavras por si só não é considerado suficiente para uma compreensão de leitura satisfatória (Corso \& Salles, 2009; Viana et al., 2013). Além dessa habilidade, considerada básica, a compreensão de leitura exige a elaboração de uma representação mental do conteúdo do texto, e assim apreendê-lo seguindo uma hipótese lógica, formal e fundamentada para extrair o significado global transmitido pela mensagem lida. Esse processo se torna viável por meio das habilidades cognitivas de alto nível, fomentadas pela memória e a noção de mundo que a criança possui (Cunha, Silva, \& Capellini, 2012) 
84

No que se refere à consciência fonológica, apesar de apresentar menor contribuição para a compreensão de leitura na amostra avaliada, conforme resultado apresentado ressalta-se a importância pela associação que tem sido demonstrada em estudos realizados anteriormente (Mota \& Correa, 2010; Spinillo et al., 2014; Suehiro \& Santos, 2015).

Outra informação importante deste estudo refere-se à memória de trabalho fonológica. A memória de trabalho fonológica tem sido considerada como uma habilidade da linguagem relacionada à consciência fonológica.

Este estudo evidencia que a memória de trabalho está associada com habilidades de compreensão da leitura, porque considera-se que a compreensão da leitura requer que partes do texto sejam mantidas, temporariamente, no sistema de memória de trabalho para, então, ser analisada e integrada. Desta forma parece que os recursos da memória de trabalho são importantes na execução de inferências, na habilidade de integrar informações e no monitoramento do próprio processo de compreensão leitora.

Quanto à correlação das habilidades de compreensão leitora com a memória de trabalho fonológica verificou-se uma correlação forte e significativa para o item DURANTE A LEITURA em: apoio articulatório e pseudopalavras (2 e 5 sílabas), perde-se na linha e pseudopalavras (5 sílabas) substitui letras e palavras com pseudopalavras (5 sílabas), transpõe sílabas ou palavras com pseudopalavra (5 sílabas), Repete palavras ou frase com pseudopalavras (2, 3, 4 e 5 sílabas). Ainda via fonólogica, via lexical, leitura vacilante, leitura fluente, pontuação, substitui letras ou palavras, transpõe sílabas ou palavras com dígitos de ordem direta. Considerando o item DEPOIS DA LEITURA obteve-se correlação forte e significância estatistica em Identifica organização do texto espontaneamente com pseudopalavras (2 sílabas) e com dígitos de ordem direta

Segundo Montgomery (2003), a memória de trabalho (MT) é um sistema de processamento e armazenamento de informações em curto prazo que mantém o pensamento, a aprendizagem e a comunicação

Um estudo que validou teste de memória de trabalho fonológica comprovou a influência da idade, da escolaridade e da extensão das não-palavras no desempenho das crianças, já que as mais velhas e com maior escolaridade apresentaram melhor desempenho, o que justifica o melhor resultados dos escolares deste estudo em pseudopalavras, uma vez que são estudantes do 9 ano e 
encontram-se na faixa etária de 13 a 17 anos. Outro fato observado foi que o desempenho das crianças de todas as faixas etárias diminui conforme o número de sílabas das não-palavras aumenta. Isso ocorre pelo fato das não-palavras serem retidas por um determinado tempo na memória de trabalho. Assim, quanto maior o número de sílabas das não-palavras, maior a dificuldade do processo subvocal da memória de trabalho (SANTOS, BUENO,2003).

Barbosa et. al (2015) em seu estudo a avaliação da memória de trabalho fonológica forneceu informações importantes sobre o padrão de desenvolvimento dos 11 aos 13 anos. As crianças mais velhas, alunos da 6ª série, recordaram mais palavras e pseudopalavras que as crianças mais novas. Em particular, as análises da pontuação segregada de acordo com o número de sílabas ajudam a compreender isso. O desempenho das crianças de $6^{\mathbf{a}}$ série foi superior para palavras com duas ou mais sílabas, além disso, o efeito de tamanho de palavra surgiu apenas para itens polissilábicos. Esse efeito foi mais acentuado para crianças de $5^{\text {a }}$ série, pois os resultados mostraram que o incremento de sílabas foi acompanhado pela queda no desempenho.

No que se refere à prova de repetição de dígitos, comprovou-se que sujeitos recordam mais dígitos na ordem direta do que na ordem inversa, resultado este que corrobora com o presente estudo. A ordem inversa apresenta maior grau de complexidade, estando assim relacionada com o executivo central, enquanto em ordem direta estaria relacionada com a alça fonológica. Sabe-se ainda que, na ordem direta, crianças foram capazes de memorizar uma média de cinco dígitos e na ordem inversa, três dígitos. Já os adultos foram capazes de memorizar cinco dígitos na ordem direta e quatro dígitos na ordem inversa (FIGUEIREDO, NASCIMENTO, 2007).

De acordo com os estudos realizados por Alloway e colaboradores (2004), a memória de trabalho tem relação direta no desempenho das tarefas de consciência fonológica, sendo a memória de trabalho capaz de reter e manipular temporalmente a informação, enquanto participa de tarefas cognitivas como raciocínio, compreensão e aprendizagem. Acredita-se que quanto maior for essa capacidade de processamento, maiores serão os recursos cognitivos disponíveis para a tarefa de compreensão da leitura, apesar de que a compreensão requer capacidades que vão além do processamento fonológico, tais como: conhecimento 
86

prévio; capacidade de realizar inferências; dentre outros (JUSTI, ROAZZI, 2012, NASCIMENTO, AMORIM, 2016).

Um outro estudo realizado por Picollo e Sales (2013) investigou a relação entre leitura (palavras e texto), memória de trabalho, quociente de inteligência (QI) e vocabulário em crianças (2a- $5^{\underline{a}}$ séries) de escolas públicas. Analisou-se também qual dessas habilidades melhor contribui para explicar o desempenho em leitura. Realizaram-se análises com e sem crianças com Ql abaixo da média. Primeiro, avaliaram-se 57 crianças (9-11 anos) em QI, vocabulário, leitura de palavras isoladas, compreensão de leitura textual e quatro tarefas de memória de trabalho. Uma segunda análise foi feita com 47 crianças, todas com inteligência média. A relação entre leitura, memória de trabalho e vocabulário mostrou-se moderada. 0 vocabulário foi o melhor preditor do desempenho em leitura (palavras e texto) do que as medidas de memória de trabalho na amostra total. $\mathrm{Na}$ análise feita com crianças sem déficit intelectual (Wasi), as tarefas que avaliam o componente fonológico e o executivo central da memória de trabalho contribuíram, independentemente do vocabulário, para a leitura de palavras.

O funcionamento inadequado de um ou mais componentes da memória de trabalho está associado/relacionado com as dificuldades de aprendizagem e ao baixo rendimento escolar. Crianças que enfrentam dificuldades de aprendizagem podem apresentar limitações na capacidade de armazenar e/ou organizar informações processadas de forma adequada e precisa para a execução de tarefas acadêmicas e/ou motoras. Pesquisas evidenciam estreitas associações entre a capacidade de crianças em idade escolar em armazenar e manipular conteúdo relativo a memória de trabalho e o progresso escolar nos domínios da linguagem, matemática. (Zanela e Valentini, 2016)

No que tange à correlação das habilidades de velocidade de leitura com a memória de trabalho fonológica destaca-se correlação forte e estatisticamente significante em: Tempo da leitura silenciosa com pseudopalavras ( 5 sílabas) e dígitos em ordem direta, número de palavras por minuto da leitura silenciosa com pseudopalavras ( 5 sílabas), Tempo da leitura oral (segundos) com pseudopalavras ( 5 sílabas) e digitos em ordem direta, número de palavras por minuto da leitura oral com pseudopalavras ( 5 sílabas) e digitos em ordem direta, corroborando estudos anteriores Salgado e Capellini (2008) que indicaram que escolares com melhores habilidades de leitura de palavras lêem um texto com maior velocidade. Esse dado 
aponta para a relação entre automatismo em leitura de palavra e velocidade de leitura de texto.

O escolares apresentaram uma leitura mais precisa o que pode ter influenciado seu desempenho na compreensão final do texto, concordando com os estudos anteriores que sugeriram uma relação entre precisão e rapidez no reconhecimento de palavras e compreensão de leitura, pois quanto mais rápida for a identificação de cada palavra, maior a capacidade da memória de trabalho consagrada às operações de análise sintática, de integração semântica dos constituintes da frase e de integração das frases na organização textual, processos importantes para a compreensão da leitura (Fletcher, 2009 e STOTHARD, 2004) .

Sugere-se que o tempo e a velocidade de leitura aumentam nos escolares sem dificuldades enquanto naqueles que têm dificuldade não ocorre este aumento, fazendo com que as diferenças nos desempenhos se tornem mais significativas, 0 mesmo ocorrendo com relação à compreensão, podendo o tempo e a velocidade de leitura ter influenciado na compreensão visto que existe uma relação entre estes fatores, pois quanto mais rápido for a identificação de cada palavra, maior a capacidade da memória de trabalho dedicada aos processos importantes para a compreensão da leitura Salgado e Capellini, 2008)

A velocidade está diretamente relacionada ao padrão de fluência de leitura. Este, por sua vez, apresentou-se relacionado com a repetição de pseudopalavras e com a CF no nível da palavra e da rima e mais fortemente com a consciência fonêmica. Speece e Ritchey (2012) também verificaram através de medidas de correlação que crianças com bom desempenho em memória de trabalho e CF apresentaram bom nível de fluência em leitura. Consideraram, igualmente, que habilidades no nível da palavra (tanto fluência quanto precisão) tornaram-se os melhores preditores de fluência textual.

É pertinente reconhecer as limitações desse estudo, visto que o trabalho foi realizado com um grupo de alunos pertencentes ao $9^{\circ}$ ano do Ensino Fundamental de uma escola pública, em determinada faixa etária, observando suas dificuldades e avanços na leitura. No entanto, a pesquisa pode e deve ser aplicada a um número maior de escolares dependendo dos objetivos propostos para a melhoria de qualidade de vida e a análise do tema em questão, ou seja, a compreensão 
88

leitora, norteando assim o trabalho de profissionais que lidam com as dificuldades dos escolares. 
7 Conclusão 



\section{CONCLUSÃO}

Não houve diferença estatisticamente significante quando se comparou o desempenho nas habilidades do processamento fonológico entre meninos e meninas apresentando desempenhos semelhantes nas atividades avaliadas.

As habilidades de leitura tiveram uma correlação forte e estatisticamente significativa no item Após a leitura nos aspectos: relato sem ajuda de perguntas, uso de conhecimento prévio para inferir sem perguntas, uso de relato com ajuda de perguntas.

Quanto às habilidades de Compreensão Leitora e comparação entre os gêneros observou-se que também não houve diferença estatística.

A consciência fonológica influenciou mais no desempenho da leitura e escrita do que a habilidade silábica, havendo o maior score de erros no nível fonêmico.

A velocidade está diretamente relacionada à fluência de leitura. Os escolares apresentaram uma leitura mais precisa no reconhecimento de palavras e compreensão de leitura.

Quanto a correlação das habilidades de compreensão leitora com a memória de trabalho fonológica verificou-se uma correlação forte e significativa para o item Durante a leitura.

Portanto, este estudo demonstrou que a compreensão leitora apresenta uma conexão eficiente com os elementos subjacentes do processamento fonológico, influenciando a prática de leitura no desempenho dos escolares. 

8 Referências 



\section{REFERÊNCIAS BIBLIOGRÁFICAS}

ALLOWAY, T. P.; GATHERCOLE, S. E.; WILLIS, C. E.; ADAMS, A. A structural analysis of working memory and related cognitive skills in young children. Journal Experimental Child Psychology, v. 7, n. 87, p. 85-106, jul., 2004.

ALVES, G. L. O Trabalho Didático na Escola Moderna: Formas Históricas. Campinas: Autores Associados, 2005.

ANTHONY, J. L.; LONIGAN, C. J. The nature of phonological Awareness: converging evidence from four studies of Preschool and Early Grade School children. Journal of educacional. Psychology, v. 96, n. 1, p. 43-55, 2004.

ARAÚJO, M. J. F. S. A competência leitora de alunos do ensino fundamental: uma proposta de intervenção. 2015. 165 f. Dissertação (Mestrado em Letras) - Programa de Pós-Graduação em Letras. Universidade Federal do Rio Grande do Norte, 2015.

BADDELEY, A. Working memory: looking back and looking forward. Nat. Rev. Neurosci. V.4, p. 829-839, 2003

BARBOSA, G. K. A.; RODRIGUES, A. M. R.; OlIVEIRA, M. S. A utilização de estratégias de leitura: Reflexões sobre a habilidade da compreensão leitora. Revista Contemporânea de Educação, Rio de Janeiro, n. 11, jan./jul. 2011.

BARRERA, S. D.; MALUF, M. R. Consciência Metalingüística e alfabetização: um estudo com crianças da primeira série do ensino fundamental. Psicologia: Reflexão e Crítica, v. 14, n.3, p. 491-502, 2003.

BASTOS, M. G. A Formação de professores para o diagnóstico das dificuldades de leitura e escrita. Fortaleza: UECE, 2003. P.143

BRASIL. Ministério da Educação. Instituto Nacional de Estudos e Pesquisas Educacionais Anísio Teixeira. Diretoria de Avaliação da Educação Básica. SAEB/ Prova Brasil 2011 - Primeiros Resultados. 2012. Disponível em: <http://download.inep.gov.br/educacao_basica/prova_brasil_saeb/resultados/2012/S aeb_2011_primeiros_resultados_site_Inep.pdf>. Acesso em: 30 mar. 2013. 
BRASIL. Ministério da Educação. PDE: Plano de Desenvolvimento da Educação: Prova Brasil: Ensino Fundamental: Matrizes de Referência, Tópicos e Descritores. Brasília: MEC, SEB; Inep, 2008.

BRASIL. Ministério da Educação. Secretaria de Educação Fundamental. Parâmetros Curriculares Nacionais: terceiro e quarto ciclos do ensino fundamental: língua portuguesa. Brasília: MEC/SEF, 1998.

BRIZZOLARA, D. et al. Do phonologic and rapid automatized naming deficits differentially affect dyslexic children with and without a history of language delay? A study of Italian dyslexic children. Cogn. Behav. Neurol., v. 19, n. 3, p. 141-149, Sep. 2006.

BROWN, D. (1994). Principles of language learning and teaching. Prentice - Hall Anglewood Cliffs Duffy, G. G., Roehler, L. R., Sivan, E., Rackliffe, G., Book, C., Meloth, M., Vavrus, L., Wesselman, R., Putnam, J. \& Bassiri, D. (1987). The effects of explaining there asoning associated withus ingreading strategies. Reading Research Quarterly, 22, 347-368

CAPELLINI, S. A, FERREIRA, T. L., SALGADO, C. A., \& CIASCA, S. M. (2007). Desempenho de escolares bons leitores, com dislexia e com transtorno do déficit de atenção e hiperatividade em nomeação automática rápida. Revista da Sociedade Brasileira de Fonoaudiologia, 12(2), 114-119.

CARDOSO-MARTINS, C., \& PENNINGTON, B. F. (2001). Qual é a contribuição da nomeação seriada rápida para a habilidade de leitura e escrita? Evidência de crianças e adolescentes com e sem dificuldades de leitura. Psicologia: Reflexão e Crítica, 14(2), 387-397.

CÁRNIO, M. S.; SANTOS, D. Evolução da consciência fonológica em alunos de ensino fundamental. Pró-Fono Revista de Atualização Científica. Barueri (SP), v. 17, n. 2, p. 195-200, maio-agosto, 2005.

Carvalho, I. A. De; Alvarez, A. M.; Caetano, A. L. Perfil de Habilidades Fonológicas, 1ํㅡㄹ edição, 1998, 12p. Editora Via Lettera. 
CIA, F. \& BARHAM, E. J. (2008). Estabelecendo relação entre autoconceito e desempenho acadêmico de crianças escolares. Psico, 39(1), 21-27.

CIELO, C. A. Habilidades em consciência fonológica em crianças de 04 a 08 anos de idade. Pró-Fono Revista de Atualização Científica, Barueri (SP), v. 14, p. 287478, 2002.

CIRINO, P. T.; ISRAELIAN, M. K.; MORRIS, M. K.; MORRIS, R. D. Evaluation of the doubledeficit hypotheses in college students referred for learning difficulties. Journal of Learning Desabilities, v. 38, n. 1, p. 29-44, January-February, 2005.

CLARKE, P. et al. Individual differences in RAN and reading: A timing analysis. J Res Read, v. 28, p. 73-86, 2005

CORREA, J.; COELHO, C.G.L. Desenvolvimento da Compreensão Leitora através do Monitoramento da Leitura. Revista: Psicologia: Reflexão e Crítica 201023 (3)

COSTA, A. C. Consciência fonológica: relação entre desenvolvimento e escrita. Dissertação (Mestrado em Linguística Aplicada). Pontifícia Universidade Católica do Rio Grande do Sul. 168 f. Porto Alegre, 2002

CUNHA, V. L. O.; CAPELLINI, A. S. Construção e validação de instrumento de avaliação da compreensão de leitura para escolares do terceiro ao quinto ano do Ensino Fundamental. Codas, São Paulo, v. 26, n. 1, p. 28-37, 2014.

DENCKLA, M. \& RUDEL, R. (1976). Rapid Automatized Naming (RAN): Dyslexia differentiated from other learning disabilities. Neuropsychologia, 14, 471-479

DENCKLA, M. B. \& RUDEL, R. Rapid "Automatized" naming of pictures, objects, colors, and letters, and numbers by normal children. Cortex 10, 186-202, July 1974Psicol. teor. prat. vol.15 no.2 São Paulo ago. 2013

DIAS, N. M., et al. Avaliação da leitura no Brasil: revisão da literatura no recorte 2009 a 2013- Revista Psicologia: Teoria e Prática, 18 (1), 113 â€'128. São Paulo, SP, jan. â€'abr. 2016. ISSN 1516 â€'3687 (impresso), ISSN 1980 â€'6906 online).http://dx.doi.org/10.15348/1980â€'6906/psicologia.v18n1p113â€'128.Sistema de avaliação : às cegas por pares (double blind review) 
DOCKRELL, J.; MCSHANE, J. Crianças com dificuldades de aprendizagem: uma abordagem cognitiva. Tradução de Andréa Negrada. Porto Alegre: Artes médicas, 2000, 208p.

DUFFY, G. G., et al (1987). The effects of explaining the reasoning associated with using reading strategies. Reading Research Quarterly, 22, 347-368.

DUKE. N. K., \& Pearson, P. D. (2002). Effective Practices for Developing Reading Comprehension. Em A. E. Farstrup \& S. J. Samuels (Orgs.), What Research Has to Say About Reading Instruction (pp. 205-242). Newark, Del: Internacional Reading Association.

EHREN, B. J. Looking for evidende-based practice in reading comprehension instruction. Topics in Language Disorders, v.25, n.4, p. 310-321, 2005.

EHREN, B. J. Results of a Two-Year Study on the Effectiveness of STRUCTURE Your Reading, a Strategic Reading Intervention, in Inclusive Middle School classes STRUCTURE YOUR READING Profile, July 2012

EHREN, B. J. STRUCTURE Your Reading: A strateroutine for promoting strategic reading. Winter Springs, FI: Student Success, Initiatives, 2008.

FERNANDES, G. B.; CRENITTE, P. A. P. O conhecimento de professores de $1^{\underline{a}}$ a $4^{\underline{a}}$ série quanto aos distúrbios da leitura e escrita. Rev. CEFAC, Campinas, v.10, n. 2, p. 182-190, 2008.

FERREIRA, A. A.; CONTE, K. M. \& MARTURANO, E. A. (2011). Meninos com queixa escolar: Autopercepções, desempenho e comportamento. Estudos de Psicologia, 28(4), 443-451

FLETCHER J. M.; LYONS, G. R.; FUCHS, L. S.; BARNES, M. A. Transtornos de aprendizagem da identificação à intervenção. Porto Alegre: Artmed; 2009.

FLORES-MENDOZA, C. E., MANSUR-ALVES, M., LELÉ, A. J., \& BANDEIRA, D. R. (2007). Inexistência de diferenças de sexo no fator $g$ (inteligência geral) e nas habilidades específicas em crianças de duas capitais brasileiras. Psicologia: Reflexão e Crítica, 20(3), 499-506. 
FREITAS, G. C. M. Consciência Fonológica e aquisição da escrita: um estudo longitudinal. Tese (Doutorado em Linguística Aplicada). Universidade Católica do Rio Grande do Sul. 132 f. Porto Alegre, 2003.

FREITAS, G. C. M. Sobre a Consciência Fonológica. In: LAMPRECHT, R. R. Aquisição Fonológica do Português. Perfil de desenvolvimento e subsídios para terapia. Porto Alegre: Artes Médicas, 2004.

FIGUEIREDO, V. L.; NASCIMENTO, E. Desempenhos nas duas tarefas do subteste dígitos do WISC-III e do WAIS-III. Psicol Teor Pesqui. 2007;23(3):313-8.

GAGNÉ, E. D.; YEKOVICH, C. W.; YEKOVICH, F. R. The Cognitive Psychology of School Learning. 2. ed. New York, USA: Harper Collins, 1993.

GAJRIA, M. et al. Improving comprehension of exposity text in students with LD: A research synthesis. Journal of Learning Disabilities, v.40, p. 210-225, 2007

GINDRI, G.; KESKE-SOARES, M.; MOTA, H. B. Comparação do desempenho de crianças pré-escolares e de primeira série em tarefas envolvendo a memória de trabalho. Rev. Soc. Bras. Fonoaudiol., v. 10, n. 4, p. 201-6, 2007.

GRAIG, S. A. The effects of on apted interactive writing intervention on kindergarten. Reading Research Quartely, v. 38, n. 4, October-November- December, 2003.

GRAY, A.; McCUTCHEN, D. Young readers' use of phonological information: phonological awareness, memory, and comprehension. Journal of Learning Disabilities, v. 39, n. 4, p. 325-333, July-August, 2006.

GODOY, D. M. A. O papel da consciência fonológica no processo de alfabetização. Pró-Fono Revista de Atualização Científica, Barueri (SP), v. 15, n. 3, p. 241-250, setembro-dezembro, 2003.

GONÇAlVES, T. S.; CRENITTE, P. A. P. Concepções de Professoras de Ensino Fundamental sobre os transtornos de Aprendizagem. Rev. CEFAC. 2014 Mai-Jun; 16(3): 817-829 
100

GUEDIM, T. F. G. Programa de compreensão leitora em adolescentes: tradução e adaptação [TESE]. Bauru: Universidade de São Paulo - Faculdade de Odontologia de Bauru; 2017.

GUIMARÃES, S. R. K. Aprendizagem da leitura e da escrita: o papel das habilidades metalinguísticas. São Paulo: Vetor, 2005. 257p.

GOMBERT, J. E. (1990). Le développement métalinguistique. Paris: PUF

GOUGH, P.; LARSON, K.; YOPP, H. A estrutura da consciência fonológica. In. C. Cardoso-Martins (Ed.), Consciência fonológica e alfabetização. Petrópolis: Vozes, 1995, p.15-35.

HAGE, S. R. V.; GRIVOL, M. A. Desempenho de crianças normais falantes do português em prova de memória de trabalho fonológica. CAD Comum Ling. 2009;1(1):61-9. 28. Aguado G. Trastorno específico

HAY, I.; ELIAS, G.; FIELDING-BARNSLEY, R.; HOMEL, R.; FREIBERG, K. Language Delays, Reading Delays, and Learning Difficulties: Interactive Elements Requiring. Multidimensional Programming. Journal of Learning Disabilities, v. 40, n. 5, p. 400-409, September-October, 2007

HULME, C. THOMSON, C. M. LAWRENCE, A. Speech rate and development of short-term memory span. J Exp Child Psychol.1984;38(2):241-53.

INEP. Instituto Nacional de Estudos e Pesquisas Educacionais Anísio Teixeira. Descrição dos Níveis de Escala de Desempenho de Língua Portuguesa - SAEB: $3^{\underline{a}}$ série do Ensino Médio. 2011. Disponível em: <http://download.inep.gov.br/educacao _basica/prova_brasil_saeb/escala/2011/escala_desempenho_lingua_portuguesa_m edio.pdf $>$. Acesso em: 2 jan. 2013

INEP. Instituto Nacional de Estudos e Pesquisas Educacionais Anísio Teixeira, \& Ministério da Educação. (2001). PISA 2000: Relatório Nacional. Brasília, DF. Retrieved October 08, 2007, from http://www.cipedya.com/doc/140404

INEP. Instituto Nacional de Estudos e Pesquisas Educacionais Anísio Teixeira. Prova Brasil e Saeb: Semelhanças e diferenças. 2011. Disponível em: 
<http://portal.inep.gov.br/web/prova-brasil-e-saeb/semelhancas-e-diferencas>. Acesso em: 1 jan. 2013. [Links]

IZQUIERDO, I. Memória. Porto Alegre: Artmed. 2002. 96p.

JOLY, M. C. R. A. (2006). Escala de estratégias de leitura para etapa inicial do ensino fundamental. Estudos de Psicologia, 23(3), 271-278

JONES, M. W. et al. Dyslexic and non-dyslexic reading fluency: Rapid automatized naming and the importance of continuous lists. Psych Bull Rev, v. 16, p. 567-572, 2009.

JONES, M. W. et al. Elucidating the component processes involved in dyslexic and non-dyslexic reading fluency: An eye-tracking study. Cognition, v.3, p. 389-407, 2008.

JONES, M. W. et al. What automaticity deficit? Activation of lexical information by readers with dyslexia in a rapid automatized naming Stroop-switch task. J Exp Psychol Learn Mem Cogn, v. 42, n. 3, p. 465-474, Mar. 2016.

JONG, C. G. W. et al. $A D H D$, and their comorbidity from a dual route perspective. Child Neuropsychol, v. 18, p. 467-486, 2012.

JONG, P. F. D. Phonological awareness and the use of phonological similarity in letter-sound learning. Journal of Experimental Child Psychology, vol.10, JanuaryFebruary, 2007.

JUSTI, C. N. G. ROAZZI, A. A contribuição de variáveis cognitivas para a leitura e a escrita no português brasileiro. Psicol. Reflex. Crit. [periódico na internet] 2012 [acesso em 24 de novembro de 2013]; 25 (3):605-14.

KAMINSKI, T. I.; MOURA, H. B.; CIELO, C.A. Vocabulário expressivo e consciência fonológica: correlações destas variáveis em crianças com desvio fonológico. Rev. Soc. Bras. Fonoaudiologia. São Paulo, v. 16, n. 2, p. 174-181, 2011.

KAMPS, D. et al. Effects of small-group Reading instruction and curriculum differences for students most at risk in kindergarten. Two-year results for secondary- 
102

and-tertiary-level interventioons. Journal of Learning Disabilities, v.41, n.2, p.101114,2008

$\mathrm{KIM}$ et al. A randomized experiment of a mixed-methods literacy intervention for struggling readers in grades 4-6: effects on word reading fluency. Reading and Writing: An Interdisciplinary Journal, v.23, n.9, p. 1109-1129, Oct. 2010

KINTSCH, W. (1988). The role of knowledge in discourse comprehension: $A$ construction-integration model. Psychological Review, 95, 163-182.

KINTSCH, W., \& VAN DIJK, T. A. (1978). Toward a model of text comprehension and production. Psychological Review, 85, 363-394.

KLEIMAN, A. B. Texto e leitor - Aspectos Cognitivos da Leitura. Campinas, SP: Editores, 2013.

KOPKE, H. F. (2001). Estratégias em compreensão da leitura: conhecimento e uso por professores de língua portuguesa. Tese de doutorado em linguística. Faculdade de Filosofia, Letras e Ciências Humanas, Universidade de São Paulo. São Paulo.

KOPKE, H. F. (1997). Estratégias para Desenvolver a Metacognição e a Compreensão de Textos Teóricos na Universidade. Psicologia Escolar e Educacional, 1 (2-3), 59-67.

LASCH, S. S.; MOTA, H. B. \& CIELO, C. A. Consciência fonológica: o desempenho de meninos e meninas bilíngues e monolíngues. Rev. CEFAC[online]. 2010, vol.12, n.2, pp.202-209. Epub Oct 02, 2009. ISSN 1982-0216. http://dx.doi.org/10.1590/ S1516-18462009005000047.

LAZZAROTO, C.; CIELO, C. A. Consciência fonológica e sua relação com a alfabetização. Revista da Sociedade Brasileira de Fonoaudiologia, v. 7, n 2, p. 1524, 2005.

LEFFA, V. J. Interpretar não é compreender: um estudo preliminar sobre a interpretação de texto. In: Vilson J. Leffa; Aracy Ernst(Org.). Linguagens: metodologia de ensino e pesquisa. Pelotas: Educat, 2012, p. 253-269. 
LOPES-SILVA, J. B., Moura, R. J, Wood, G., \& Haase, V. G. (2015). Processamento fonológico e desempenho em aritmética: uma revisão da relevância para as dificuldades de aprendizagem. Temas em Psicologia, 23, 157-173.

MACIEL, A. G. Motivação e Intervenção em Estratégias de Aprendizagem para Compreensão Leitora. 2012. 134f. Dissertação (Mestrado em Educação) Universidade Estadual de Londrina, Londrina. 2012.

MACHADO, A. C.; CAPELLINI, S. A. Dados preliminares de um programa de intervenção para compreensão leitora por meio da técnica de cloze. Rev. psicopedag., São Paulo, v. 33, n. 101, p. 144-153, 2016 . Disponível em: $<$ http://pepsic.bvsalud.org/scielo.php?script=sci_arttext\&pid=S0103-8486201600020 0004\&lng=pt\&nrm=iso $>$. Acessos em 20 out. 2017.

MARCUSCHI, L. A. Gêneros virtuais emergentes no contexto da tecnologia digital. In MARCUSCHI \& XAVIER, A. C. S. (orgs). Hipertexto e gêneros digitais: novas formas de construção do sentido. Rio de Janeiro: Lucerna, 2004.

MARTIN, M. de M.M; NAVAS, A.L; Comparação do desempenho em compreensão em diferentes condições de apresentação do texto. Distúrb Comun, São Paulo, 22(2):95-106, agosto 2010.

MELCHIOR, M. R.; GABRIEL, R. Tecendo conexões entre cognição, linguagem e leitura, 2014, cap. 13, pag.189

MICHAELIS. Dicionário prático da língua portuguesa. 2. ed. São Paulo: Editora Melhoramentos, 2009. (Michaelis prático)

MIRANDA-CASAS, A. et al. Comprensión de textos de estudiantes com Trastorno por Déficit de Atención/Hiperactividad: ¿qué papel desempeñanlas funciones ejecutivas?. Rev Neurol, v. 50, p. 135-142, mês 2010. /Supl 3/.

MISRA, M., KATZIR, T., WOLF, M., \& POLDRAC, R. (2004). Neural systems of rapid automatized naming in skilled readers: Unraveling the RAN - reading relationship. Scientifi c Studies of Reading, 8(3), 241-256. 
104

MONTGOMERY, J. W. Working memory and compreension in children with specific language impairment: what we know so far. J Commun Disord. 2003; 36 (3): 221-31.

MOOJEN, S.; ET AL. Consciência fonológica: Instrumento de avaliação sequencial. São Paulo: Casa do Psicólogo, 2003.

MORAIS, A. G. Concepções e metodologias de alfabetização: por que é preciso ir além da discussão sobre velhos "métodos"? Secretaria de Educação Básica, Brasília: DF. 2006. Disponível em: < http://portal.mec.gov.br/seb/arquivos/pdf/ Ensfund/alf_moarisconcpmetodalf.pdf>. Acessado em: 02 de julho de 2010

NASCIMENTO, A; AMORIM, S. S. Aspectos educacionais relacionados a Leitura: da teoria à prática. Nuances: estudos sobre Educação, Presidente Prudente, v. 27, n. 1, p. 315-328, jan./abr. 2016.

NICOLIELO-CARRILHO, A. P.; HAGE, S. R. V. Estratégias metacognitivas de leitura de crianças com distúrbio de aprendizagem. CODAS [online]. 2017, vol.29, n.3 [cited 2017-10-20], e20160091. Available from: <http://www.scielo.br/scielo.php? script=sci_arttext\&pid=S2317-17822017000300305\&lng=en\&nrm=iso > .

Epub May 15, 2017. ISSN 2317-1782. <http://dx.doi.org/10.1590/23171782/20172016091>

OLIVEIRA, A. M.; CAPELLINI, S. A. (2010). Desempenho de escolares na adaptação brasileira da avaliação dos processos de leitura. Pró-Fono Revista de Atualização Científica, 22(4), 555-560.

OliveIRA, A. P. M. Prova Brasil como Política de Regulação da Rede Pública do Distrito Federal. 2011. 274f. Dissertação (Mestrado em Educação) - Programa de Pós-Graduação em Educação, Universidade de Brasília, Brasília, 2011.

OLIVEIRA, K. L., BORUCHOVITCH, E., \& SANTOS, A. A. A. (2007). Compreensão de leitura em alunos de sétima e oitava séries do ensino fundamental. Revista Semestral da Associação Brasileira de Psicologia Escolar e Educacional, 11, 41-49.

PAES, C. T. S.; PESSOA, A. C. R. G. Habilidades fonológicas em crianças não alfabetizadas e alfabetizadas. Revista CEFAC, v. 7, n. 2, 149-57, abril-junho, 2005. 
PAULA, F.V. (2002). Conhecimento metacognitivo de crianças de $3^{\text {a }}$ série que apresentam dificuldades na aquisição da leitura. Dissertação de Mestrado. USP, São Paulo.

PAULA, G.R. (2002). A terapia em consciência fonológica no processo de alfabetização. Dissertação de Mestrado. UFSM, Santa Maria.

PESTUN, M. S. V. Consciência fonológica no início da escolarização e o desempenho ulterior em leitura e escrita: estudo correlacional. Estudos de Psicologia, v. 10, n. 3, p. 407-412. 2005.

PELLEGRINI, M. C. K. (1996). Avaliação dos níveis de compreensão e atitudes frente à leitura em universitários. Dissertação de Mestrado. Faculdade de Ciências Humanas, Universidade São Francisco, Bragança Paulista/SP.

PICCOLO, L. R.; SALLES, J. F. Vocabulário e memória de trabalho predizem desempenho em leitura de crianças. Revista Psicologia: Teoria e Prática, São Paulo, v.15, n.2, p. 180-191, 2013.

PIOVEZAN, N. M., \& CASTRO, N. R. (2008). Compreensão e estratégias de leitura no ensino fundamental. Psic: revista da Vetor Editora, 9(1), 53-62

PONTES, V. L.; DINIZ, N. L. F.; MARTINS-REIS, V. O. Parâmetro e estratégias de leitura e escrita utilizados por crianças de escolas pública e privada. Rev. CEFAC, Campinas, v. 15, n.4, p. 827-836, 2013.

PUOLAKANAHO, A. Very early phonological and languages kills: estimating individual risk of reading disability. Journal of Child Psychology and Psychiatry, v. 48, n. 9, p. 923-931, 2007.

RESCHLY, D. J. Learning Disabilities Identification: Primary Intervention, Secondary Intervention, and Then What? Journa lof Learning Disabilities, v. 38, n. 6, p. 510-515, November-December, 2005.

ROMERO, M. V. Desenvolvimento das habilidades em consciência fonológica e relação com leitura e compreensão leitora. Dissertação (Mestrado em Distúrbios da 


\section{Referêncías}

106

Comunicação Humana). Universidade Federal de Santa Maria. 168 f. Santa Maria, 2004.

ROSAL, A. G. C. et al. Contribuições da consciência fonológica e nomeação seriada rápida para aprendizagem inicial da escrita. Rev. CEFAC, Campinas, v. 18, p.74-85, 2016.

ROSENBLATT, L. M. (2004). The transactional theory of reading and writing. In R.B. Ruddell \& N.J. Unrau (Eds), Theoretical Models and processes of reading (5th ed., p. 1363-1398). Newark, D E: International Reading Association.

RYDER, J. F.; TUNMER, W. E.; GREANEY, K. T., Explicit instruction in phonemic awareness and phonemically based decoding skill as an intervention strategy for struggling readers in whole language classrooms. Read Writ: Interd. Journal, v. 21, p. 349-369, 2008

SALES, J. P. Práticas de leitura e mediação pedagógica como fatores fundamentais para o desenvolvimento da compreensão leitora na alfabetização. 2013. 120 f., il. Monografia (Licenciatura em Pedagogia)_Universidade de Brasília, Brasília, 2013.

SALGADO, C. A.; CAPELLINI, S. A. Programa de remediação fonológica em escolares com dislexia do desenvolvimento. Pró-Fono Rev Atual Cient. 2008; 20(1):31-6

SALLES, J. F.; PARENTE, M.A.M.P. Avaliação da leitura e escrita de palavras em crianças de $2^{\mathrm{a}}$ série: abordagem neuropsicológica cognitiva. Psicol Refl Crít.,Porto Alegre, v. 20, n. 2, p. 220-228, 2007.

SANTOS, F.H. BUENO, O.F. Validation of the Brazilian children's test of pseudo word repetition in portuguese speakers aged 4 to 10 years. Braz J Med Biol Res. 2003;36(1):1533-47.

SARAIVA, R. A.; MOOJEN, S.; MUNARSKI, R. Avaliação da Compreensão Leitora de Textos Expositivos - São Paulo- 2ª edição, 2006, 104 p. 
SAVAGE, R. S.; et al. Relationship among rapid digit naming, phonological processing, motor automaticity, and speech perception in poor, average, and good readers and spellers. Journal of Learning Disabilities, v. 38, n. 1, p. 12-28, 2005.

SILVA, C.. S586e Eficácia de um programa de remediação fonológica e leitura em escolares com distúrbio de aprendizagem. - Marília, 2009. 197 f. ; 30 m. Dissertação (Mestrado em Educação) - Faculdade de Filosofia e Ciências, Universidade Estadual Paulista, 2009. Bibliografia: f. 115-126 Orientador: Dra. Simone Aparecida Capellini

SILVA, S. F.; MOURA, E. S. Compreensão leitora e raciocinio lógico não verbal: evidencias de alunos com necessidades educativas especiais na classe regular. Rev. Pós graduação: desafios contemporaneos, v.1, n. 1, 2014.

SIM-SIM, I. \& col. O Ensino da Leitura: A Compreensão de Textos. Ministério da Educação. Direção - Geral de Inovação e de Desenvolvimento Curricular. Lisboa, Novembro, 2007. 1ª Edição. 7.500 exe.

SIQUEIRA, L.S. Estudo da memória de trabalho em adultos e idosos normais. Dissertação. Santa Maria (RS): Universidade Federal de Santa Maria, Centro de Ciências da Saúde; 2006

SOLÉ, I. (1998). Estratégias de leitura. 6ª edição. Porto Alegre: Artes Médicas.

SPEECE, D. L., RITCHEY, K. D. A longitudinal study of the development of oral reading fluency in young children at risk for reading failure. Journal of Learning Disabilities. 2005;38:387-399.

STOTHARD, S. Avaliação da compreensão da leitura. In: SNOWLING, M.; STACKHOUSE, J. (org). Dislexia, fala e linguagem. São Paulo: Artmed; 2004. p. 121-142.

SUEHIRO, A. C. B. \& SANTOS, A. A. A. D. (2015). Compreensão de leitura e consciência fonológica: evidências de validade de suas medidas. Estudos de Psicologia (Campinas), 32(2), 201-211. doi:10.1590/0103-166X2015000200005 
108

SYVERSON, P. An ecological view of literacy learning. Literacy, v. 42, n. 2, p. 109117, 2008.

TENORIO, S. M. P. C. P.; AVILA, C. R. B. Processamento fonológico e desempenho escolar nas séries iniciais do ensino fundamental. Rev. CEFAC [online]. 2012, vol.14, n.1, pp.30-38. Epub 23-Set-2011. ISSN 1982-0216. http://dx.doi.org/10.1590/S1516-18462011005000099.

TODOS PELA EDUCAÇÃO. Dados do Brasil. 2012. Disponível em: $<$ http://www.todospelaeducacao.org.br/educacao-no-brasil/numeros-do-brasil/brasil/ $\mathrm{pdf} />$. Acesso em: 30 mar. 2013

TRUMAN, A.; HENNESSEY, N. W. The locus of the naming difficulties in children with dyslexia: Evidence of inefficient phonological encoding. Lang Cognitive Proc, v. 21, p. 361-393, 2006.

UVO, M. F. C.; GERMANO, G. D.; CAPELLINI, S. A. Desempenho de escolares com transtorno do déficit de atenção com hiperatividade em habilidades metalinguísticas, leitura e compreensão leitora. Rev. CEFAC, São Paulo, v. 19, n. 1, p. 7-19, Feb. 2017 Available from <http://www.scielo.br/scielo.php?script =sci_arttext\&pid=S151618462017000100007\&lng=en\&nrm=iso $>$.Accesson 20 Oct. 2 017. <http://dx.doi. org/10.1590/1982-0216201719115815>

VUKOVIC, R. K.; SIEGEL, L. S. The double-deficit hypothesis: a comprehensive analysis of the evidence. J Learn Disabil, v. 39, n. 1, p. 25-47, 2006.

WAGNER R. K. et al. Changing relations between phonological processing abilities and word-level reading as children develop from beginning to skilled readers: a 5year longitudinal study. Dev Psychol., v. 33, n. 3, p. 468-479, May 1997.

WAGNER, R.K.; TORGESEN, J.K. The Nature of Phonological Processing and Its Causal Role in the Acquisition of Reading Skills. Psychological Bulletin, v. 101, n. 2, p.192-212. 1987

WALCOTT, C. M.; SCHEEMAKER, A.; BIELSKI, K. A Longitudinal Investigation of Inattention and Preliteracy Development. J. of Attention Disorders, v. 14, n. 1, p. 7985, Jul. 2010 
WANZEK, J.; VAUGHN, S. Response to Varying Amounts of Time in Reading Intervention for Students With Low Response to Intervention. Journal of Learning Disabilities, v. 41, n. 2, p. 126-142, march-april, 2008.

WOLF, M. et al. Naming-speed processes, timing, and reading: a conceptual review. J Learn Disabil, v. 33, n. 4, p. 387-407, 2000.

ZANELLA, L. W.; VALENTINI.N.C. Como funciona a Memória de Trabalho? Influências na aprendizagem de crianças com dificuldades de aprendizagem e crianças com desordem coordenativa desenvolvimental. Medicina (Ribeirão Preto), v.49, n.2, p.160-174, 2016

ZORZI, J. L. Aprendizagem e distúrbio da linguagem escrita: questões clínicas e educacionais. Porto Alegre: Ed. Artmed, 2003.

ZWIERS, J. Building reading comprehension habits in grades 6-12: a toolkit of classroom activities. 2. ed. Newark, International Reading Association, 2010. 240 p. 

9 Anexos 



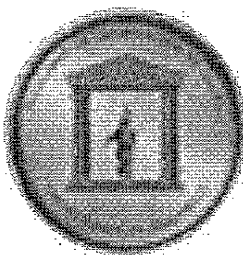

\section{Universidade de São Paulo \\ Faculdade de Odontologia de Bauru}

DEPARTAMENTO DE FONOAUDIOLOGIA

\section{TERMO DE CONSENTIMENTO LIVRE E ESCLARECIDO (TCLE)}

Solicitamos sua autorização para a participação voluntária do (a) menor na pesquisa "Proposta de Avaliação da Compreensão Leitora para adolescentes do Ciclo II do Ensino Fundamental". Esta pesquisa pretende verificar e melhorar a compreensão de leitura dos participantes. Participarão deste estudo 30 adolescentes que frequentam a Sala de Leitura da Escola Estadual "Prof. Luiz Castanho de Almeida". O Programa terá a duração de 30 horas no total, sendo 1 hora por aluno em duas vezes por semana com o acompanhamento da Pesquisadora.

Os testes que serão aplicados serão os seguintes: 1-Avaliação da compreensão leitora de textos expositivos: tem como objetivo avaliar a leitura através de um texto com leitura silenciosa e oral, com relatos do que compreendeu do texto. 2Consciência fonológica: avalia a consciência de sílabas e de fonemas. 3- Acesso ao léxico mental: mede a velocidade do aluno ao ler a nomeação de cores, dígitos, letras e objetos. 4- Prova de Memória de Trabalho Fonológica: permite a avaliação da memória com a repetição de palavras e dígito.

Este Termo está de acordo com as normas do Comitê de Ética e Pesquisa em Seres Humanos. A identidade dos participantes não será revelada durante todas as fases da Pesquisa (sigilo), bem como a privacidade das informações prestadas. Ainda, não haverá prejuízo aos que desistirem de participar deste estudo. O próprio adolescente, bem como seus responsáveis, tem o direito de recusar a participação ou retirar seu consentimento em qualquer fase da pesquisa, sem sofrer penalizações. Você receberá os resultados de todos os procedimentos realizados, assim como suas dúvidas serão esclarecidas sempre que houver necessidade. $O$ adolescente receberá todo tipo de ajuda que for necessária. Caso seja observada dificuldades na compreensão de textos, haverá possibilidade de 


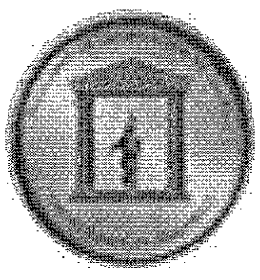

\section{Universidade de São Paulo Faculdade de Odontologia de Bauru}

\section{DEPARTAMENTO DE FONOAUDIOLOGIA}

\section{TERMO DE CONSENTIMENTO LIVRE E ESCLARECIDO (TCLE)}

Solicitamos sua autorização para a participação voluntária do (a) menor na pesquisa "Proposta de Avaliação da Compreensão Leitora para adolescentes do Ciclo II do Ensino Fundamental". Esta pesquisa pretende verificar e melhorar a compreensão de leitura dos participantes. Participarão deste estudo 30 adolescentes que frequentam a Sala de Leitura da Escola Estadual "Prof. Luiz Castanho de Almeida". O Programa terá a duração de 30 horas no total, sendo 1 hora por aluno em duas vezes por semana com o acompanhamento da Pesquisadora.

Os testes que serão aplicados serão os seguintes: 1-Avaliação da compreensão leitora de textos expositivos: tem como objetivo avaliar a leitura através de um texto com leitura silenciosa e oral, com relatos do que compreendeu do texto. 2Consciência fonológica: avalia a consciência de sílabas e de fonemas. 3- Acesso ao léxico mental: mede a velocidade do aluno ao ler a nomeação de cores, dígitos, letras e objetos. 4- Prova de Memória de Trabalho Fonológica: permite a avaliação da memória com a repetição de palavras e dígito.

Este Termo está de acordo com as normas do Comitê de Ética e Pesquisa em Seres Humanos. A identidade dos participantes não será revelada durante todas as fases da Pesquisa (sigilo), bem como a privacidade das informações prestadas. Ainda, não haverá prejuízo aos que desistirem de participar deste estudo. O próprio adolescente, bem como seus responsáveis, tem o direito de recusar a participação ou retirar seu consentimento em qualquer fase da pesquisa, sem sofrer penalizações. Você receberá os resultados de todos os procedimentos realizados, assim como suas dúvidas serão esclarecidas sempre que houver necessidade. $O$ adolescente receberá todo tipo de ajuda que for necessária. Caso seja observada dificuldades na compreensão de textos, haverá possibilidade de 
Universidade de São Paulo

Faculdade de Odontologia de Bauru

\section{DEPARTAMENTO DE FONOAUDIOLOGIA}

Pelo presente instrumento que atende às exigências legais, o $\mathrm{Sr}$. (a) portador da cédula de identidade , após leitura minuciosa das informações constantes neste TERMO DE CONSENTIMENTO LIVRE E ESCLARECIDO, devidamente explicada pelos profissionais em seus mínimos detalhes, ciente dos serviços e procedimentos aos quais serásubmetido, não restando quaisquer dúvidas a respeito do lido e explicado, DECLARA e FIRMA seu CONSENTIMENTO LIVRE E ESCLARECIDO concordando em participar da pesquisa proposta. Fica claro que o participante da pesquisa, pode a qualquer momento retirar seu CONSENTIMENTO LIVRE E ESCLARECIDO e deixar de participar pesquisa e ciente de que todas as informações prestadas tornar-se-ão confidenciais e guardadas por força de sigilo profissional (Art. $9^{\circ}$ do Código de Ética Odontológica, ou Art. $13^{\circ}$ do Código de Ética Fonoaudiológico -para outras profissões verificar o Código de Ética do sigilo profissional correspondente).

Por fim, como pesquisador(a) responsável pela pesquisa, DECLARO o cumprimento do disposto na Resolução CNS n ${ }^{\circ} 66$ de 2012, contidos nos itens IV.3 e IV.4, este último se pertinente, item IV.5.a e na întegra com a resolução CNS n466 de dezembro de 2012

Bauru, SP, de de

Assinatura do Participante da Pesquisa

Luci Neire Annize Manoel

Pesquisadora 


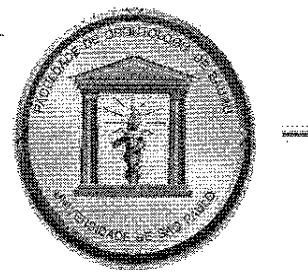

\title{
Universidade de São Paulo Faculdade de Odontologia de Bauru
}

\author{
Departamento de Fonoaudiologia
}

\section{TERMO DE ASSENTIMENTO DO MENOR}

Você está sendo convidado(a) como voluntário(a) a participar da pesquisa "Proposta de avaliação da compreensão leitora de adolescentes do Ciclo ll do Ensino Fundamental". Neste estudo faremos uma avaliação para analisar como está sua compreensão de leitura.

O motivo que nos leva a estudar esse assunto é a importância de adquirir informações a respeito da situação atual sobre o desempenho na compreensão de leitura dos alunos do ciclo II do ensino fundamental de escola pública. Com isso, será possivel orientar diretores e professores quanto às difjculdades dos alunos que poderão ser observadas nesta pesquisa e, ainda, elaborar estratégias em sala de aula para que estas dificuldades sejam minimizadas, $e_{y}$ consequentemente, 0 desempenho dos alunos melhore em relação à compreensão de leitura. Para você ter uma ideia, os resultados da avaliação do Saeb em 2012 mostrou que $45,95 \%$ dos alunos do $5^{\circ}$ ano e $73,04 \%$ do $9^{\circ}$ encontram-se abaixo do nível considerado ideal na compreensâo de leitura, causando dificuldades de aprendizagem que são aumentadas de uma série para a outra. Estas informações são preocupantes, e, por este motivo, torna-se urgente a avaliação e o trabalho com a estimulação das habilidades de leitura com alunos da sua série.

Os testes que você irá fazer são: 1-Avaliação da compreensão leitora de textos expositivos tem como objetivo avaliar a leitura por meio de um texto, observando a leitura silenciosa e oral, $\theta$ depois com relatos do que você compreendeu do texto. 2- Consciência fonológica: avalia a consciência dos sons da fala os quais se relacionam com as letras para você escrever as palavras corretamente e. 3- Acesso ao léxico mental: mede a velocidade para nomear cores, números, letras $e$ objetos. 4- Prova de Memória de Trabalho Fonológica: permite a avaliação da memória por meio da repetição de palavras, não palavras (palavras que não existem) e números.

A avaliação terá a duração de 1 hora em apenas um encontro com a pesquisadora.

Para participar deste estudo, o responsável por você deverá autorizar e assinar um termo de consentimento (autorização). Você não terá nenhum custo para participar desta Pesquisa. Você será esclarecido(a) em qualquer aspecto que desejar e estará livre para participar ou recusar-se. O responsável por você poderá retirar o consentimento ou interromper a sua participaçấo a qualquer momento. A sua participação é voluntária e a recusa em participar não causará qualquer modificação na forma em que é atendido(a) pela pesquisadora. Portanto, a sua vontade em participar ou não da pesquisa será respeitada. publicação.

Haverá sigilo de todos os dados fornecidos. Você não será identificado em nenhuma

Em decorrência das avaliações desta pesquisa, você poderá sentir desconforto postural por ficar uma hora sentado para realizar as atividades, bem como cansaço por ter que ficar atento neste periodo. No entanto, a pesquisadora tomará providências para que nesta situação de avaliação estes problemas sejam os mínimos possiveis, tais como organizar o ambiente com cadeiras confortáveis, iluminação adequada, sala sem ruídos competitivos e pausas nas avaliações quando necessário.

Apesar disso, você tem o direito de ressarcimento se houver despesas durante a pesquisa, tais como: cópias de textos, lanche e transporte, que serão pagos pela Pesquisadora. Caso ocorra qualquer dano (prejuizo) decorrente da pesquisa, haverá garantia de indenização a você e seus responsáveis.

Os resultados estarão à sua disposição quando finalizado este estudo Seu nome ou o material que indique sua participação não será liberado sem a permissão do responsável por você. Os dados e instrumentos utilizados na pesquisa ficarão arquivados com a pesquisadora. Este termo de assentimento encontra-se impresso em duas vias, sendo que uma via será arquivada pela pesquisadora, e a outra será fornecida a você.

Eu, portador(a) do documento de Identidade fui informado(a) dos objetivos do presente estudo de maneira

Al. Dr. Octávio Pinheiro Brisolla, 9-75 - Bauru-SP - CEP 17012-901 - C.P. 73 e-mail: depfono@fob.usp.br- Fone/FAX (0xx14) 3235-8390

http://www.fob.usp.br 


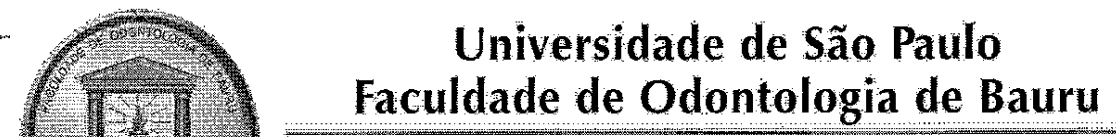

Departamento de Fonoaudiologia

clara e detalhada e esclareci minhas dúvidas. Sei que a qualquer momento poderei solicitar novas informações, e o meu responsável poderá modificar a decisão de participar se assim o desejar. Tendo o consentimento do meu responsável já assinado, declaro que concordo em participar desse estudo. Recebi uma cópia deste termo de assentimento e me foi dada a oportunidade de ler e esclarecer as minhas dúvidas.

Por fim, como pesquisadora responsável pela pesquisa, DECLARO o cumprimento do disposto na Resolução CNS n ${ }^{\circ} 466$ de 2012, contidos nos itens IV.3 e item IV.5. a e na íntegra com a resoluçäo CNS n 466 de dezembro de 2012.

Por estarmos de acordo com o presente termo o firmamos em duas vias igualmente válidas (uma via para o participante da pesquisa e outra para o pesquisador) que serão rubricadas em todas as suas páginas e assinadas ao seu término, conforme o disposto pela Resolução CNS $n^{\circ} 466$ de 2012, itens IV.3.f e IV.5.d

Bauru, SP, de de

Assinatura do Participante da Pesquisa

Luci Neire Aparecida Annize Manoel Pesquisadora

O Comitê de Ética em Pesquisa - CEP, organizado e criado pela FOB-USP, em 29/06/98 (Portaria GD/0698/FOB), previsto no item VII da Resolução CNS n 466/12 do Conselho Nacional de Saúde do Ministério da Saúde (publicada no DOU de 13/06/2013), é um Colegiado interdisciplinar e independente, de relevância pública, de caráter consultivo, deliberativo e educativo, criado para defender os interesses dos participantes da pesquisa em sua integridade e dignidade e para contribuir no desenvolvimento da pesquisa dentro de padrões éticos.

Qualquer denúncia e/ou reclamação sobre sua participação na pesquisa poderá ser reportada a este CEP:

Horário e local de funcionamento:

Comitê de Ética em Pesquisa

Faculdade de Odontologia de Bauru-USP - Prédio da Pós-Graduação (bloco E - pavimento superjor), de segunda à sexta-feira, no horário das 14 hs às 17 horas, em dias úteis.

Alameda Dr. Octávio Pinheiro Brisolla, 9-75

Vila Universitária - Bauru - SP - CEP 17012-901

Telefone/FAX(14)3235-8356

e-mail: cep@fob.usp.br 